\title{
Seasonal variability and long-term evolution of tropospheric composition in the tropics and Southern Hemisphere
}

\author{
K. M. Wai ${ }^{1}$, S. Wu ${ }^{1,2,3}$, A. Kumar ${ }^{1,2}$, and H. Liao $^{4}$ \\ ${ }^{1}$ Department of Geological and Mining Engineering and Sciences, Michigan Technological University, Houghton, MI, USA \\ ${ }^{2}$ Department of Civil and Environmental Engineering, Michigan Technological University, Houghton, MI, USA \\ ${ }^{3}$ Atmospheric Sciences Program, Michigan Technological University, Houghton, MI, USA \\ ${ }^{4}$ State Key Laboratory of Atmospheric Boundary Layer Physics and Atmospheric Chemistry (LAPC), Institute of \\ Atmospheric Physics, Chinese Academy of Sciences, Beijing, China
}

Correspondence to: K. M. Wai (kwai@mtu.edu)

Received: 17 June 2013 - Published in Atmos. Chem. Phys. Discuss.: 31 July 2013

Revised: 5 March 2014 - Accepted: 2 April 2014 - Published: 19 May 2014

\begin{abstract}
Impacts on tropospheric composition in the tropics and the Southern Hemisphere from biomass burning and other emission sources are studied using a global chemical transport model, surface measurements and satellite retrievals. Seasonal variations in observed CO at remote island sites are examined. Easter Island (eastern Pacific Ocean) is impacted indirectly by the hemispheric zonal transport of $\mathrm{CO}$ due to the burning in southern Africa/South America, via the westerlies. An increasing trend in $\mathrm{CO}$ by $0.33 \mathrm{ppb} \mathrm{yr}^{-1}$ in the past decade at Ascension Island is attributed to the combined effects of South American/southern Africa burnings and the increases in $\mathrm{CH}_{4}$ level. Compared to Easter Island and Ascension Island, much less contribution from biomass burning to atmospheric $\mathrm{CO}$ is found at the island of Mahé (western Indian Ocean), where the total CO peaks in JanuaryFebruary, reflecting the contributions of anthropogenic emissions from India. We also examine the 2000-2050 changes in atmospheric composition in the tropics and the Southern Hemisphere driven by future changes in emissions and climate. Changes in solar radiation (UV) over South Atlantic Ocean (SAO) in future January have dominant effects on the $\mathrm{O}_{3}$ distribution. More than $55 \%$ of $\mathrm{O}_{3}$ concentrations over the SAO in both present-day and future September are not directly affected by the emissions (including lightning) over the adjacent two continents but are attributable to the transport of $\mathrm{O}_{3}$ from surrounding areas due to $\mathrm{CO}$ and $\mathrm{CH}_{4}$ oxidation and stratospheric intrusion. High $\mathrm{NO}_{\mathrm{x}}$ emissions in both continents in 2050s increase PAN concentrations over remote oceans at the higher southern latitudes $\left(>35^{\circ} \mathrm{S}\right)$ as far
\end{abstract}

as those near Australia, affecting the $\mathrm{O}_{3}$ budget over there. Future changes in biomass burning and anthropogenic $\mathrm{NO}_{\mathrm{x}}$ emissions in southern Africa lead to a new area of high $\mathrm{O}_{3}$ concentrations near South Africa. The resulted $\mathrm{O}_{3}$ outflow to the Indian Ocean is pronounced due to the effects of the persistent anticyclone. A general reduction in future $\mathrm{OH}$ radical concentrations is predicted over the remote marine boundary layer in the tropics and the Southern Hemisphere, as a result of the increases in $\mathrm{CH}_{4}$ and $\mathrm{CO}$ emissions.

\section{Introduction}

Emissions from biomass burning are an important source for a number of atmospheric trace gases including carbon monoxide $(\mathrm{CO})$, nitrogen oxide $\left(\mathrm{NO}_{\mathrm{x}}\right)$, ozone $\left(\mathrm{O}_{3}\right)$, and aerosols, including black carbon. Biomass burning accounts for about $30 \%$ of the global total CO source (Galanter et al., 2000). These trace gases and aerosols play important roles in tropospheric chemistry, air quality and global climate (Levine et al., 1995; Granier et al., 2000; Haywood et al., 2008). They can affect the abundance of hydroxyl radical $(\mathrm{OH})$, which is the major oxidizing agent in the troposphere.

Tropospheric composition in the Southern Hemisphere (SH) and equatorial regions is particularly sensitive to biomass burning emissions, since emissions from the combustion of fossil fuels are much lower in the $\mathrm{SH}$ and equatorial regions than in the northern midlatitudes. Previous studies, in particular the campaign of Transport and Atmospheric 
Chemistry in the Atlantic (TRACE-A) (Fishman et al., 1996), and the Southern African Fire Atmosphere Research Initiative in 1992 (SAFARI-92) (Andreae et al., 1996), have examined the contribution of biomass burning activities from southern Africa and South America to tropospheric composition and the ozone anomaly over the tropical and subtropical South Atlantic Ocean. Satellite measurements from the Total Ozone Mapping Spectrometer (TOMS) (Hsu et al., 1996; Thompson et al., 2001), MOPITT (Edwards et al., 2006) and the Tropospheric Emission Spectrometer (TES) (Jourdain et al., 2007) have also been used to detect biomass burning signatures. Most of the previous studies focused on short time periods (usually less than a year). However, there could be significant interannual variability in biomass burning emissions and atmospheric transport for the tropical regions (Allen et al., 1996; Barbosa et al., 1999; van der Werf, et al., 2006). Better understanding of the impacts of interannual variations in biomass burning emissions on tropospheric composition as well as the long-term trends is needed.

Recently, there has been increasing interest in the potential impacts of global change on atmospheric composition and air quality. All future socioeconomic scenarios developed by the Intergovernmental Panel on Climate Change (IPCC) project significant changes in global emissions of ozone precursors $\left(\mathrm{NO}_{\mathrm{x}}, \mathrm{VOC}\right.$ (volatile organic compound) and $\left.\mathrm{CO}\right)$, including emissions from biomass burning over the 21st century (Nakicenovic and Stewart, 2000). On the other hand, natural emissions of ozone precursors would also be affected by climate change. For example, $\mathrm{NO}_{\mathrm{x}}$ emission from lightning, which is a significant source for $\mathrm{NO}_{\mathrm{x}}$ in the tropics, is generally expected to increase in a warmer climate (Price and Rind, 1994; Grenfell et al., 2003; Shindell et al., 2006; Wu et al., 2008a). Since tropical ozone is very sensitive to $\mathrm{NO}_{\mathrm{x}}$ emissions from lightning (Moxim and Levy, 2000; Jenkins et al., 2003; Wu et al., 2007), the climate change implication on tropical composition could be significant. Most of the previous studies of the impacts of global change on tropospheric composition have focused on the northern midlatitudes, in particular the developed regions (e.g., Liao et al., 2006; Unger et al., 2006; Hedegaard et al., 2008; Wu et al., 2008a, b) but not the SH. Regionally, the potential effects of climate change on biomass burning in the US have been studied (e.g., Westerling et al., 2006; Spracklen et al., 2009).

The aims of this study are to (a) improve our understanding on the impacts of biomass burning on tropospheric composition in the tropics and $\mathrm{SH}$ as well as the seasonal variation and long-term trends by combining in situ measurement data and model simulations, and (b) examine the potential impacts on tropospheric composition in the tropics and $\mathrm{SH}$ driven by $2000-2050$ changes in emissions and climate.

\section{Approach and method}

We first analyze and compile surface $\mathrm{CO}$ measurements in the tropics and SH for 2002-2006. A 10-year (2001-2010) data set of surface $\mathrm{CO}$ measurement is used to determine whether there is a statistically significant trend. The measurement data are also used to evaluate the performance of a global chemical transport model (CTM) - the GEOS-Chem CTM. We then carry out model simulations to examine the perturbations to tropospheric composition associated with the projected changes in emissions and climate by the 2050s. Unless specified otherwise, the analyses of atmospheric composition in this study focus on January and September, since biomass burning activities in Africa peak in January and September and those in South America peak in September (e.g., Moxim and Levy, 2000; Sudo et al., 2002; Duncan et al., 2003; Edwards, et al., 2003; Korontzi et al., 2004; Bian et al., 2007).

\subsection{Observational data}

The NOAA/ESRL Global Monitoring Division (GMD) network surface CO data (Novelli et al., 2003; Bian et al., 2007; Novelli and Masarie, 2012) at Ascension Island $\left(7.98^{\circ} \mathrm{S}, 14.42^{\circ} \mathrm{W}\right)$, Mahé $\left(4.67^{\circ} \mathrm{S}, 55.17^{\circ} \mathrm{E}\right)$ and Easter Island $\left(27.13^{\circ} \mathrm{S}, 109.45^{\circ} \mathrm{W}\right.$ ) (Fig. 1a) are used. Monthly means and event flask data are used in model evaluation and trend analysis, respectively. The precision of the $\mathrm{CO}$ measurements is $1 \mathrm{ppb}$ at $50 \mathrm{ppb}$ and $2 \mathrm{ppb}$ at $200 \mathrm{ppb}$ (http: //ds.data.jma.go.jp/gmd/wdcgg/).

\subsection{Model description}

The GEOS-Chem model (http://geos-chem.org) v9-01-01 is used for simulations of the atmospheric chemistry and composition to study the impacts of biomass burning and other sources for present-day and future scenarios. GEOS-Chem has detailed and fully coupled ozone- $\mathrm{NO}_{\mathrm{x}}-\mathrm{VOC}$-aerosol chemistry, which can resolve more than 100 species. It has been extensively evaluated with various observational data sets (e.g., Bey et al., 2001; Fiore et al., 2003; Jaeglé et al., 2003; Li et al. 2004; Heald et al., 2006; Hudman et al., 2009; Johnson et al., 2010; Huang et al., 2013; Kumar et al., 2013).

The model is driven by assimilated (GEOS-4 data from NASA GMAO with $2^{\circ} \times 2.5^{\circ}$ horizontal resolution and 30 vertical layers) or simulated (NASA/GISS GCM simulation with $4^{\circ} \times 5^{\circ}$ horizontal resolution and 23 vertical layers) meteorological fields for present-day and future simulations, respectively. All the model runs are conducted following 1 year of model spin-up. The interface between GEOS-Chem and the GISS GCM has been described and evaluated by Wu et al. (2007) and also applied in a number of previous studies to investigate the potential effects of global change on air quality (Wu et al., 2008a, b, 2012; Pye et al., 2009; Lam et al., 
a)

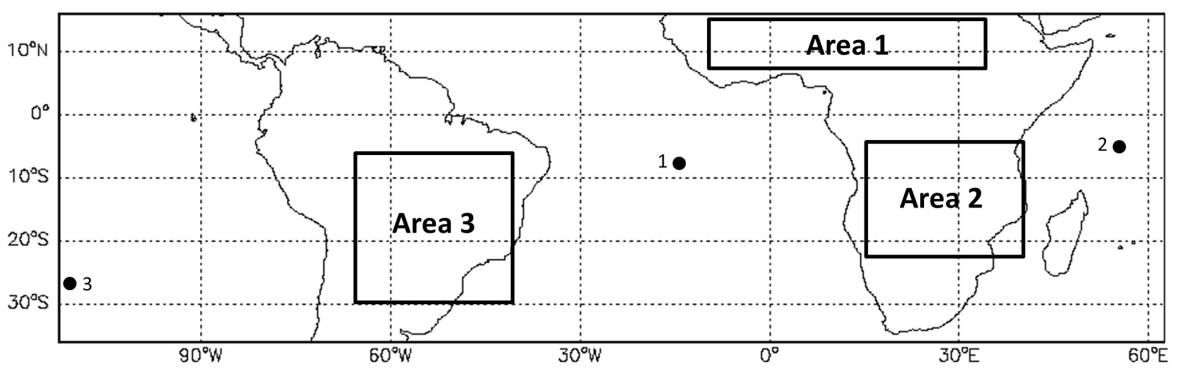

b)

c)
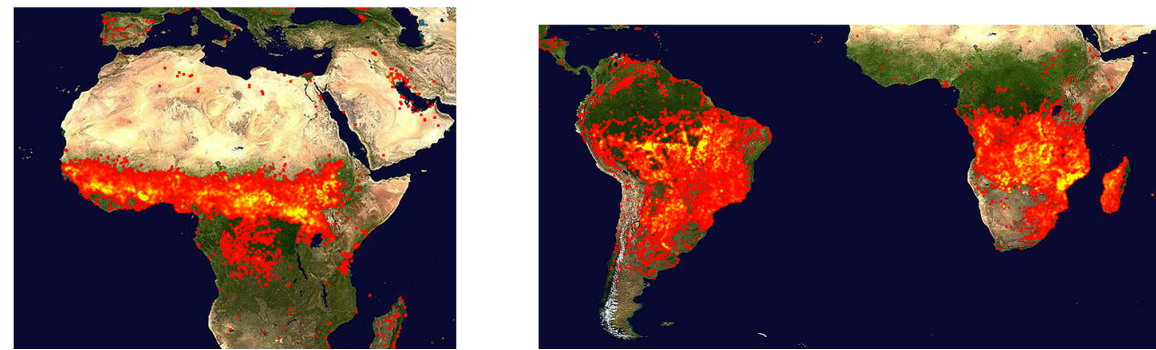

Figure 1. (a) Location of ground-level remote monitoring stations selected for the study: 1. Ascension Island, 2. Mahé, and 3. Easter Island. Locations of biomass burning (Areas 1-3) are also shown. The 10-day fire maps detected by MODIS in (b) January (21-30 January 2005) and (c) September (8-17 September 2006).

2011; Hickman et al., 2010; Wang et al., 2013; Jiang et al., 2013).

For the present-day simulations, emissions from fossil fuel combustion follow the EDGAR global anthropogenic emissions inventory and are updated with regional emission inventories including the criteria air contaminant emission inventory for Canada, the Big Bend Regional Aerosol and Visibility Observational (BRAVO) emission inventory for Mexico, the emission inventory for Asia based on Streets et al. (2006) and Zhang et al. (2009); the National Emission Inventory (NEI) 2005 inventory for the United States and the Co-operative Programme for Monitoring and Evaluation of the Long-range Transmission of Air Pollutants in Europe (EMEP) emission inventory for Europe. Biomass burning emissions of $\mathrm{CO}, \mathrm{NO}_{\mathrm{x}}$ and NMVOCs (non-methane volatile organic compounds) are based on the Global Fire Emission Database version 2 (GFEDv2) (van der Werf et al., 2006). Biofuel emissions are from Yevich and Logan (2003). Biogenic VOC emissions are calculated online by the Model of Emissions of Gases and Aerosols from Nature (MEGAN) scheme (Guenther et al., 2006). Lightning $\mathrm{NO}_{\mathrm{x}}$ emissions in GEOS-Chem are parameterized as a function of deep convective cloud top height (Price and Rind, 1992; Wang and Jacob, 1998) and are distributed vertically following Pickering et al. (1998), with recent updates by Murray et al. (2013).

To examine in detail the potential impacts of global change on atmospheric chemistry and composition in the $\mathrm{SH}$ and the equatorial region, we carry out GEOS-Chem simulations driven by meteorological fields archived from the GISS
GCM simulations. Following Wu et al. (2008a), we apply the IPCC A1B scenario for the 2000-2050 changes in anthropogenic emissions of ozone and aerosol precursors in the model based on data from the IMAGE socioeconomic model (IMAGE Team, 2001; Streets et al., 2004). Anthropogenic emissions include those associated with fossil fuel, biofuel, and human-induced biomass burning. Natural emissions of ozone precursors including $\mathrm{NO}_{\mathrm{x}}$ from lightning and soil, and NMVOCs from vegetation, are computed locally within the model on the basis of meteorological variables and hence allowed change in response to climate change. The potential impacts of climate change on biomass burning (e.g., Westerling et al., 2006; Spracklen et al., 2009) are not accounted for in this study. A comparison of the present-day and future emissions in areas of interest is shown in Table 1. Possible 2000-2050 changes in stratosphere-troposphere exchange (STE) of ozone is not accounted for in this study. In all simulations, STE for ozone is represented by the Synoz flux boundary condition (McLinden et al., 2000) with an imposed global annual mean STE flux of $500 \mathrm{Tg} \mathrm{O}_{3} \mathrm{yr}^{-1}$.

\section{Results and discussion}

\subsection{Impacts of biomass burning on $\mathrm{CO}$ for the present day}

The atmospheric lifetime of $\mathrm{CO}$ in the troposphere ranges from weeks to months (Duncan et al., 2007). The relative long lifetime of $\mathrm{CO}$ makes it a tracer suitable for studying the 
Table 1. Comparison of present-day and future emissions in Africa and South America

\begin{tabular}{|c|c|c|c|c|c|c|c|c|c|}
\hline \multirow[b]{2}{*}{ Species } & \multicolumn{3}{|c|}{$\begin{array}{l}\text { Northern Africa }{ }^{1} \\
\text { (in Jan) }\end{array}$} & \multicolumn{3}{|c|}{$\begin{array}{l}\text { Southern Africa }{ }^{2} \\
\text { (in Sep) }\end{array}$} & \multicolumn{3}{|c|}{$\begin{array}{l}\text { South America } \\
\quad \text { (in Sep) }\end{array}$} \\
\hline & Present-day & Future & Change (\%) & Present-day & Future & Change (\%) & Present-day & Future & Change (\%) \\
\hline \multicolumn{10}{|l|}{$\mathrm{CO}(\mathrm{Tg})$} \\
\hline Biomass burning 4 & 23.4 & 31.1 & 33 & 22.0 & 13.7 & -38 & 18.4 & 57.3 & 212 \\
\hline Fossil fuel & 0.35 & 2.00 & 477 & 0.44 & 1.75 & 302 & 0.85 & 0.89 & 5 \\
\hline \multicolumn{10}{|l|}{$\mathrm{NO}_{\mathrm{X}}(\mathrm{Tg} \mathrm{N})$} \\
\hline Biomass burning 4 & 0.18 & 0.20 & 12 & 0.44 & 0.24 & -46 & 0.35 & 0.82 & 134 \\
\hline Lightning & 0.042 & 0.034 & -19 & 0.021 & 0.026 & 22 & 0.056 & 0.067 & 19 \\
\hline Soil & 0.070 & 0.064 & -9 & 0.061 & 0.066 & 8 & 0.093 & 0.097 & 4 \\
\hline Fossil fuel & 0.009 & 0.095 & 956 & 0.039 & 0.189 & 381 & 0.065 & 0.175 & 171 \\
\hline
\end{tabular}

anthropogenic burning but not those driven by climate change.

long-range transport in the troposphere. Figure 2 shows the monthly $\mathrm{CO}$ variations at the remote surface measurement sites in 2002-2006. Both observational data and model simulations show large seasonal variations of $\mathrm{CO}$ concentrations at the sites on Ascension Island, Mahé, and Easter Island (Fig. 2). The seasonal variations in observed $\mathrm{CO}$ are well captured by the GEOS-Chem model, especially for those in Mahé and Easter Island. Concentrations of $\mathrm{CO}$ are systemically overestimated in Ascension Island, similar to the work by Sinha et al. (2004). The observed CO concentrations usually peak in September-October, January-February, and September-November for Ascension Island, Mahé, and Easter Island, respectively. The minimum CO concentrations are generally found in January-March, May-July, and February-March respectively at these three sites.

\subsubsection{Northern Africa burnings}

In northern Africa, the savanna burning is usually between south of the Sahara and north of the tropical rain forest near the Equator during winter-spring of the Northern Hemisphere (NH) (Fig. 1a, Area 1), which is evident by the numerous fire events presented in the MODIS fire map (Fig. 1b). The $\mathrm{CO}$ plumes from northern African burnings are transported westward or south-westward by the Harmattan flow. When the plumes encounter the cool monsoon air from the Gulf of Guinea and the Intertropical Convergence Zone (ITCZ), they are lifted above the planetary boundary layer (PBL). We use the NOAA HYSPLIT model (Draxler and Rolph, 2013; Rolph, 2013) for forward trajectory analysis, which clearly shows the rapid vertical atmospheric transport from 500 to $>3000 \mathrm{~m}$ a.s.l. within 3.5 days (Fig. 3b). In the lower free troposphere, the African easterly jet effectively enhances the long-range transport (LRT) of the CO plumes toward South America. These are indicated by the trajectories started from western Africa. The area of large-scale elevation of CO concentrations at $700 \mathrm{hPa}$ and the LRT of CO over Atlantic Ocean are captured by the model (Fig. 3a).
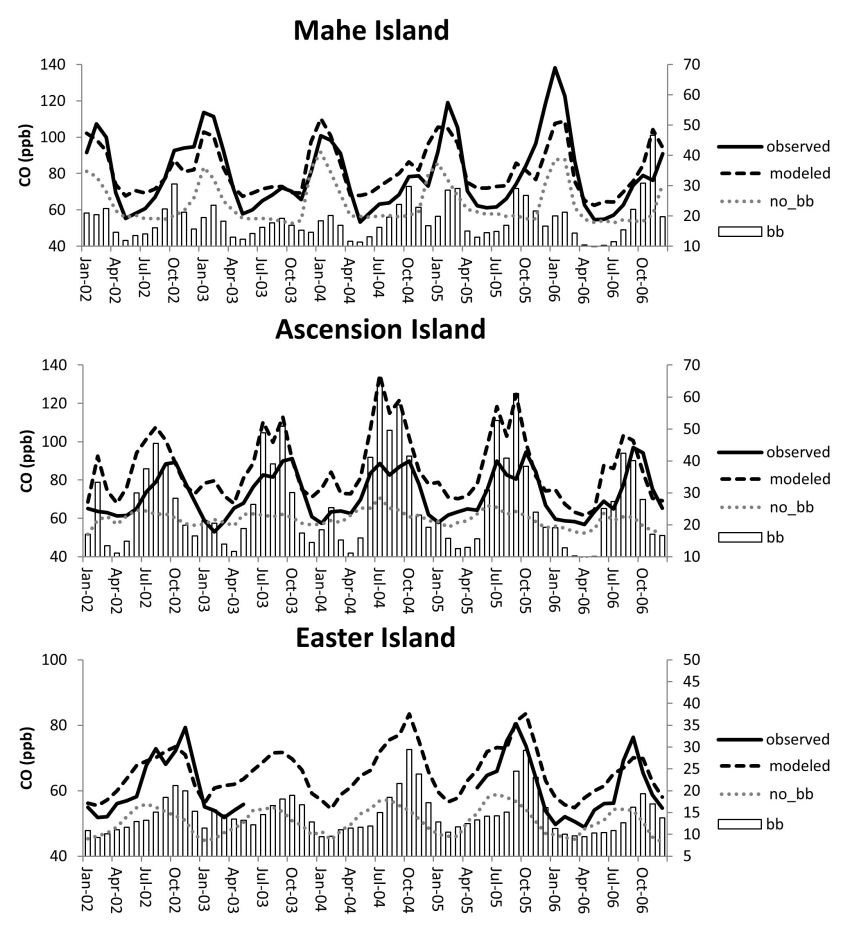

Figure 2. Variation of $\mathrm{CO}$ concentrations at the three stations in 2002-2006. "bb" means CO contributed by biomass burning, and "no_bb" means CO without contributed by biomass burning. The R.H.S. (right-hand side) scale only applies to the "bb" results.

Since the biomass burning plumes from northern Africa are generally transported westward or south-westward, they are not expected to significantly affect the atmospheric $\mathrm{CO}$ over Mahé, located in the Pacific Ocean (Fig. 1a). To examine the major sources of $\mathrm{CO}$ at Mahé, we carry out backtrajectory analysis, which indicates that air masses at Mahé are dominated by those originating from India in January and February with additional contribution from Europe via the Middle East, the Sahara and Indian Ocean (Fig. 3c). We also 
a)

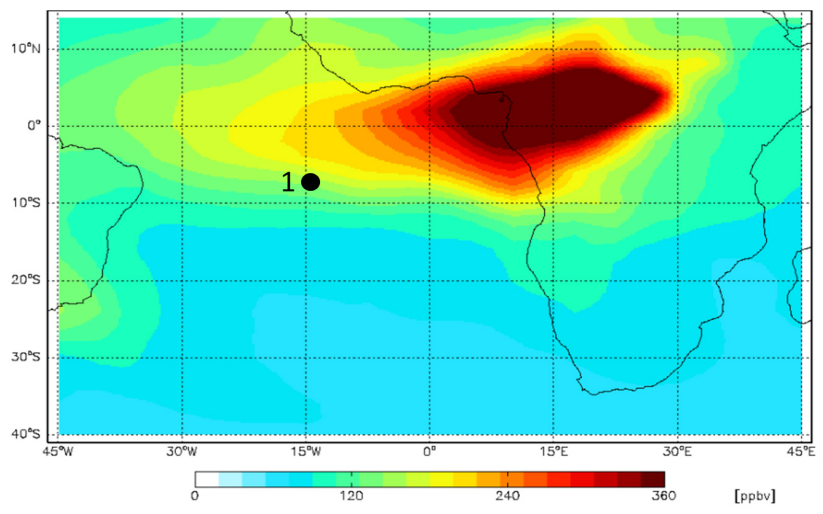

b)

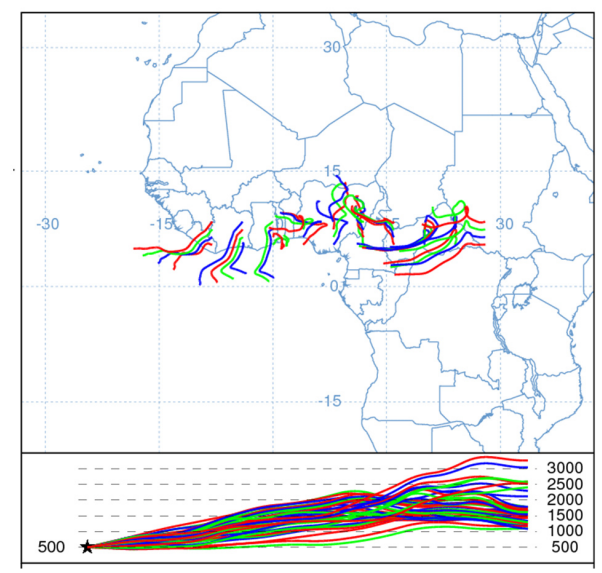

c)

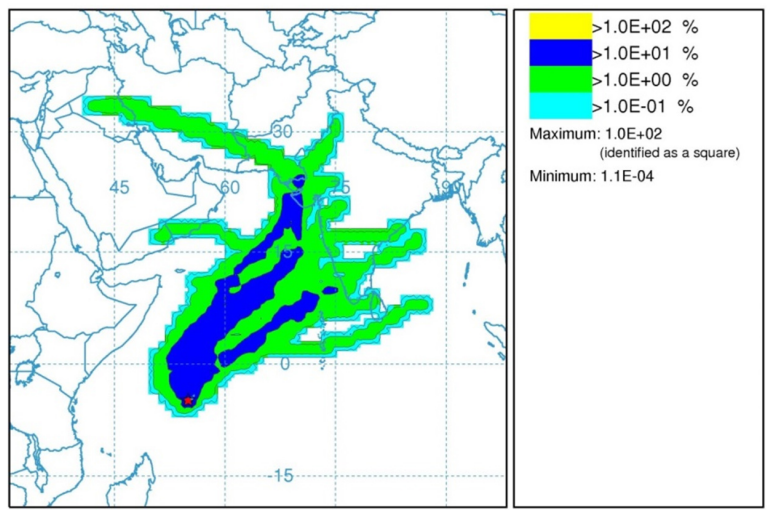

Figure 3. (a) Monthly averaged CO concentrations (ppb) computed by GEOS-Chem at $704 \mathrm{hPa}$ in January 2005. The station location (refer to Fig. 1 for station number) is also shown. (b) A plot of 3.5day forward-trajectory matrix launched on 20 January 2005 from northern Africa. (c) A monthly back-trajectory frequency (\%) plot in January 2004 when the measured CO is high at Mahé. The trajectory frequency plot includes 10-day backward trajectories launched everyday for a month from Mahé. The frequency plots in other years when the measured CO is high are included in the Supplement. perform a sensitive model simulation by excluding biomass burning sources in the model with the simulated CO concentrations indicated as "no_bb" in Fig. 2. The contributions to $\mathrm{CO}$ at Mahé from biomass burning are derived by comparing the sensitivity model results with those from the control run. It is found that the biomass burning contribution to total CO at Mahé is much less than that at the Easter Island or Ascension Island. During January-February when CO peaks at Mahé, the contribution from biomass burning is generally less than $20 \%$. With the results from the backtrajectory analysis, the January-February peaks in measured $\mathrm{CO}$ at Mahé are thus attributed to the anthropogenic emissions from India.

\subsubsection{Southern Africa burnings}

In southern Africa, the widespread burning events occur mainly in Angola, Zambia, and Democratic Republic of the Congo during July to September (Fig. 1a and, Area 2 and c). Persistent low-level easterlies/southeasterlies facilitate the westward transport of $\mathrm{CO}$ plumes from southern Africa. Three synoptic-scale high-pressure systems are located persistently over southern Africa, South America/adjacent Atlantic Ocean and Indian Ocean. They are featured with descending air and relatively low wind speeds, which limit the dispersion of the burning pollutants. Under the influence of the high-pressure system over southern Africa, the $\mathrm{CO}$ plumes tend to recirculate over the continent. Our forward trajectory analysis (figure not shown) for the period of 2002 to 2006 confirms this feature. The trajectories further suggest two main exit pathways of the CO plumes. One pathway is from southern tip of the continent to Indian Ocean and another pathway is from western part of the continent to Atlantic Ocean just south of the ITCZ. The exit pathways are well indicated by the GEOS-Chem model (Fig. 4a).

Regional elevations of $\mathrm{CO}$ over the SAO at surface level during these months in 2002-2006 due to the westward transport of the burning plumes are also evident by the measurements in Ascension Island (Fig. 2) and the modeling results (Fig. 4a). The modeling results at the island capture the peaks though overpredictions are noted as mentioned earlier. It is interesting that elevated $\mathrm{CO}$ concentrations were still measured in October when the burning activities in southern Africa decreased rapidly. This is attributed to the atmospheric recirculation (Swap et al., 1996; Edwards et al., 2006) over the Atlantic Ocean carrying high $\mathrm{CO}$ accumulated in previous months. Backward trajectory plots in October launched at Ascension Island confirm the recirculation of air masses over the SAO (Fig. 4b). As already mentioned, one exit pathway is from the southern tip of the continent to Indian Ocean. The CO plumes that followed this pathway pass south of Mahé at latitudes around $10-20^{\circ} \mathrm{S}$, resulting in no elevated $\mathrm{CO}$ being measured. 


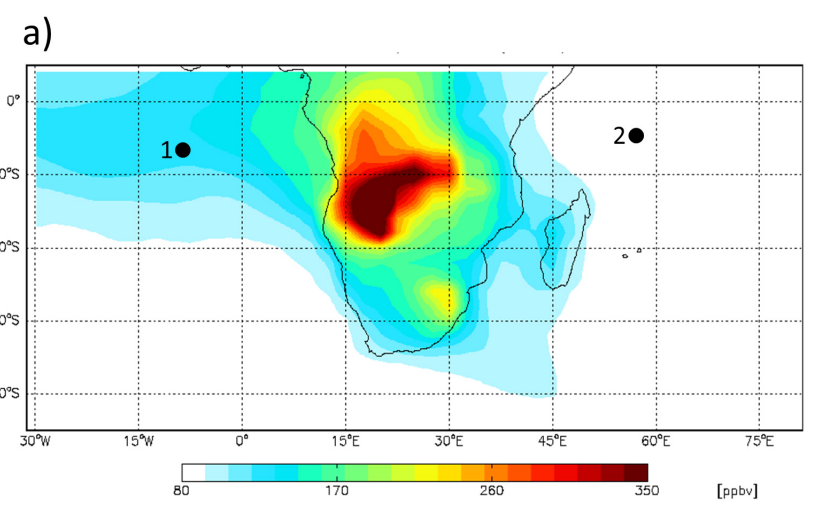

b)

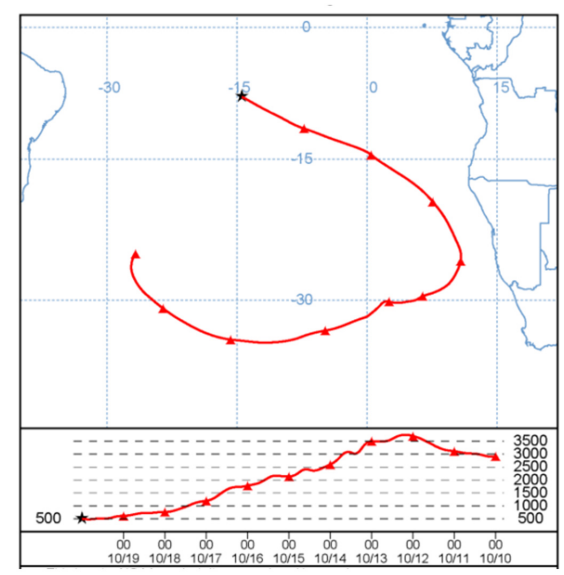

Figure 4. (a) Monthly averaged surface CO distribution over southern Africa and Atlantic Ocean in September 2005. The station locations (refer to Fig. 1 for station number) are also shown. (b) A typical 10-day backward trajectory (launched on 20 October 2003) showing recirculation of air mass over South Atlantic Ocean.

\subsubsection{South America burnings}

Most of the burning activities in South America occur in Brazil, Bolivia, Paraguay and Argentina (Fig. 1a, Area 3 and c) and generally peak in August to October. Based on the GEOS-Chem CO predictions at $704 \mathrm{hPa}$ (Fig. 5a), continental outflows of CO occur at southeast and northwest of South America. Rapid vertical export by deep convective processes is a major process to transport burning-produced pollutants from PBL to upper troposphere in South America (Anderson et al., 1996; Freitas et al., 2005; Wu et al., 2011). Once the plumes are vented to the free troposphere, the westerlies in the upper troposphere (> $8 \mathrm{~km}$ a.s.l.) effectively transport the plumes from South America towards southern Africa (Fig. 5b).

Our modeling results show that, with the prevailing northwestward atmospheric transport, biomass burning plumes from South America have little impact on atmospheric com- position over the Pacific Ocean at higher southern latitudes $\left(>10^{\circ} \mathrm{S}\right)$. Therefore, Easter Island, which is located subtropically $\left(\sim 27^{\circ} \mathrm{S}\right)$ to the west of South America, is not directly impacted by the plumes. However, both measurements and model simulations show significant seasonal variations in $\mathrm{CO}$ concentrations at Easter Island, with peaks in SeptemberNovember (Fig. 2). A major contribution to the seasonal variation of $\mathrm{CO}$ appears to be the seasonal variation of $\mathrm{OH}$, the major sink of $\mathrm{CO}$. OH peaks in summer (January/February in the Southern Hemisphere) and reaches the lowest level in winter (July/August in the Southern Hemisphere) (Seiler et al., 1984). We compared the model simulated CO concentrations from the control run with those from the sensitive model run where biomass burning emissions were excluded to further examine the potential impacts of biomass burning on the seasonal variation of $\mathrm{CO}$ at Easter Island. Figure 2 shows the $\mathrm{CO}$ levels contributed by biomass burning (i.e., $\mathrm{CO}_{\mathrm{bb}}$ equals total $\mathrm{CO}$ minus $\mathrm{CO}_{\text {no_bb }}$ ) at Easter Island, which indicates that both the $\mathrm{OH}$ seasonality and biomass burning emissions contribute to $\mathrm{CO}$ variability at Easter Island. The "bb" component of $\mathrm{CO}$ at Easter Island is mainly attributed to biomass burning emissions from Africa and South America being picked up by the persistent westerlies about $30^{\circ} \mathrm{S}$ or further southward. These biomass burning plumes are first transported across the Indian Ocean towards Australia. Then they are advected over the Pacific Ocean eventually reaching Easter Island. This transport pathway is consistent with previous studies. Rinsland et al. (2001) attributed the elevated $\mathrm{CO}$ background over Australia during October to December in 1997 to emissions from southern Africa/South America. Our backward trajectories launched from Easter Island reach Australia/New Zealand aloft during the period (Fig. 5c), which support the $\mathrm{CO}$ transport pathway by the westerlies. In addition, fire emissions from Indonesia and northern Australia could also contribute to the "bb" component of $\mathrm{CO}$ at Easter Island.

\subsection{Trend of $\mathrm{CO}$ at Ascension Island in the past decade}

Based on the above finding, Ascension Island is the only site that is impacted directly by the biomass burning emissions from southern Africa and South America. Surface CO measurements from this site with longer sampling period (20012010) are therefore studied to determine whether there has been any statistically significant trend. Figure 6 shows the $10 \mathrm{yr}$ time evolution of $\mathrm{CO}$ concentrations (ppb) at Ascension Island. The seasonal variation is evident, similar to Fig. 2, with small interannual variability. To investigate whether there is a long-term trend, a regression analysis was performed to fit the observation with the following polynomial equation:

$$
\mathrm{C}_{t}=a_{0}+a_{1} t+a_{2} \sin (2 \pi t / 365)+a_{3} \cos (2 \pi t / 365)+e_{t},
$$


a)

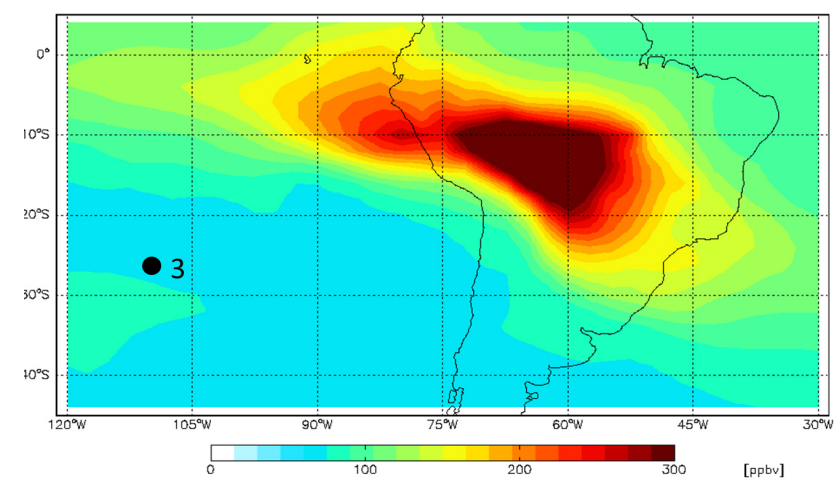

b)

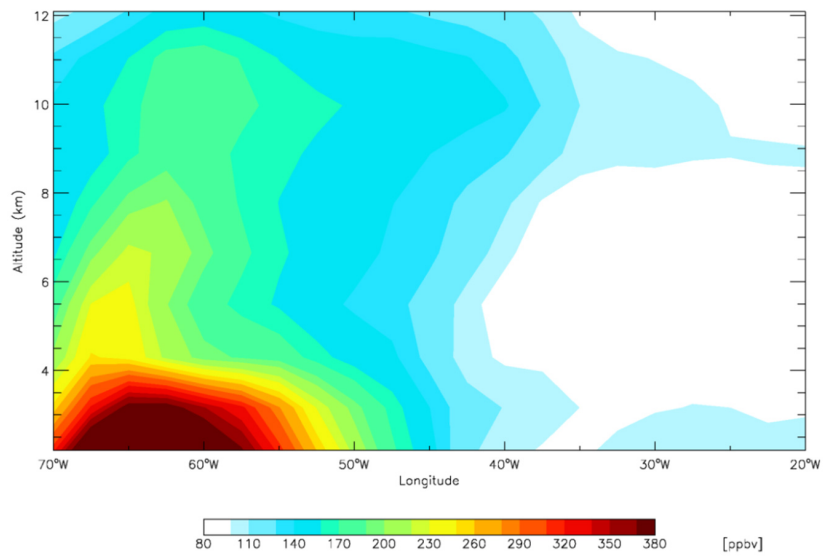

c)

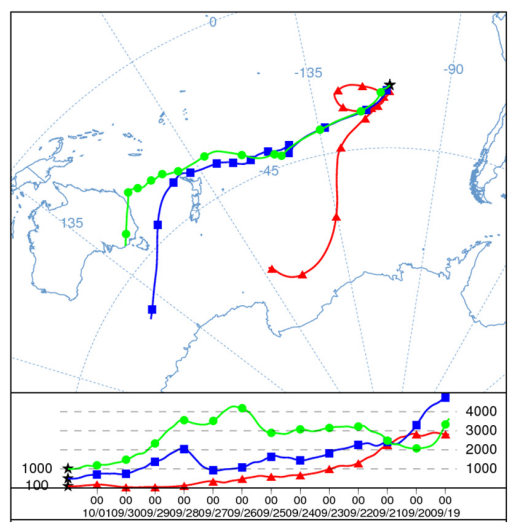

Figure 5. (a) Monthly averaged $\mathrm{CO}$ concentrations (ppb) predicted by GEOS-Chem model over South America at $704 \mathrm{hPa}$ in September 2006. The station location (refer to Fig. 1 for station number) is also shown. (b) Vertical CO distribution at $14^{\circ} \mathrm{S}$ over burning areas of South America in September 2006. (c) A typical 13-day backward trajectory launched on 2 October 2002 from Easter Island. where $\mathrm{C}_{t}$ is the mixing ratio of $\mathrm{CO}$ at time $t$ (in days); $a_{0}, a_{1}$, $a_{2}$, and $a_{3}$ are the regression coefficients; and $e_{t}$ the residual from the model.

The sinusoidal terms in Eq. (1) are used to account for the seasonal variations of $\mathrm{CO}$ concentrations. A linear term is used to indicate any possible trend over this time period. The coefficients of the equation are determined by the leastsquares method. The observational data were smoothed by a 5-day centered moving average prior to the regression analysis.

The regression analysis yields an increasing trend $\left(a_{1}=0.33 \pm 0.24 \mathrm{ppb} \mathrm{yr}^{-1}\right)$ for $\mathrm{CO}$ at Ascension Island, which is statistically significant $(p<0.01)$. Zhao et al. (2008) derived a positive trend up to 0.03 per decade for aerosol optical depth (AOD) over southern Africa (lat: 15.0 to $5.0^{\circ} \mathrm{S}$; long: 5.0 to $15.0^{\circ} \mathrm{E}$ ) in autumn for the period of 1980-2005, which was mostly attributed to biomass burning. The MODIS AOD measurements within latitudes of $30^{\circ} \mathrm{S}-$ Equator reported an increasing trend of $0.0012 \mathrm{yr}^{-1}$ over 2001-2007 (Yu et al., 2009), with biomass burning in South America/southern Africa as the major source of aerosols in this latitudinal region. Bevan et al. (2009) also reported an increasing trend of AOD due to biomass burning over the Amazon based on the ATSR data for 2000 to 2005 .

Long-term variations of $\mathrm{CO}$ can also be affected by the variations of atmospheric $\mathrm{CH}_{4}$, which provides an important source for CO. Significant increases in atmospheric $\mathrm{CH}_{4}$ concentrations have been reported since 2007 after staying relatively stable in earlier years of the past decade. An increase of $\sim 7.5 \mathrm{ppb} \mathrm{yr}^{-1}$ in $\mathrm{CH}_{4}$ was observed by the satellite instrument SCIAMACHY over the tropics (Schneising et al., 2011). The measurements from the AGAGE and CSIRO networks show renewed growth in both the $\mathrm{SH}$ and the $\mathrm{NH}$ (Rigby et al., 2008). Observations from the NOAA's global sampling network also showed increases in global $\mathrm{CH}_{4}$ during 2007 (by $8.3 \mathrm{ppb} \mathrm{yr}^{-1}$ ) and 2008 (by $4.4 \mathrm{ppb} \mathrm{yr}^{-1}$ ), especially for the $\mathrm{SH}$ and the tropics (Dlugokencky et al., 2009). These previous studies suggest that the increasing trend at Ascension Island calculated in this study is likely to be driven by an increase in biomass burning from South America/southern Africa and an increase in ambient $\mathrm{CH}_{4}$ in recent years.

We note that Worden et al. (2013) identified a slight decrease in the total CO column over the Southern Hemisphere $\left(0-60^{\circ} \mathrm{S}\right)$ for the period of 2000-2011. The discrepancy compared to the positive trend at Ascension Island identified in this study could reflect the different metrics used for atmospheric CO (column vs. surface values) as well as the different spatial coverage in these two studies. Further study would be desirable to explore in detail the causes of this discrepancy. 


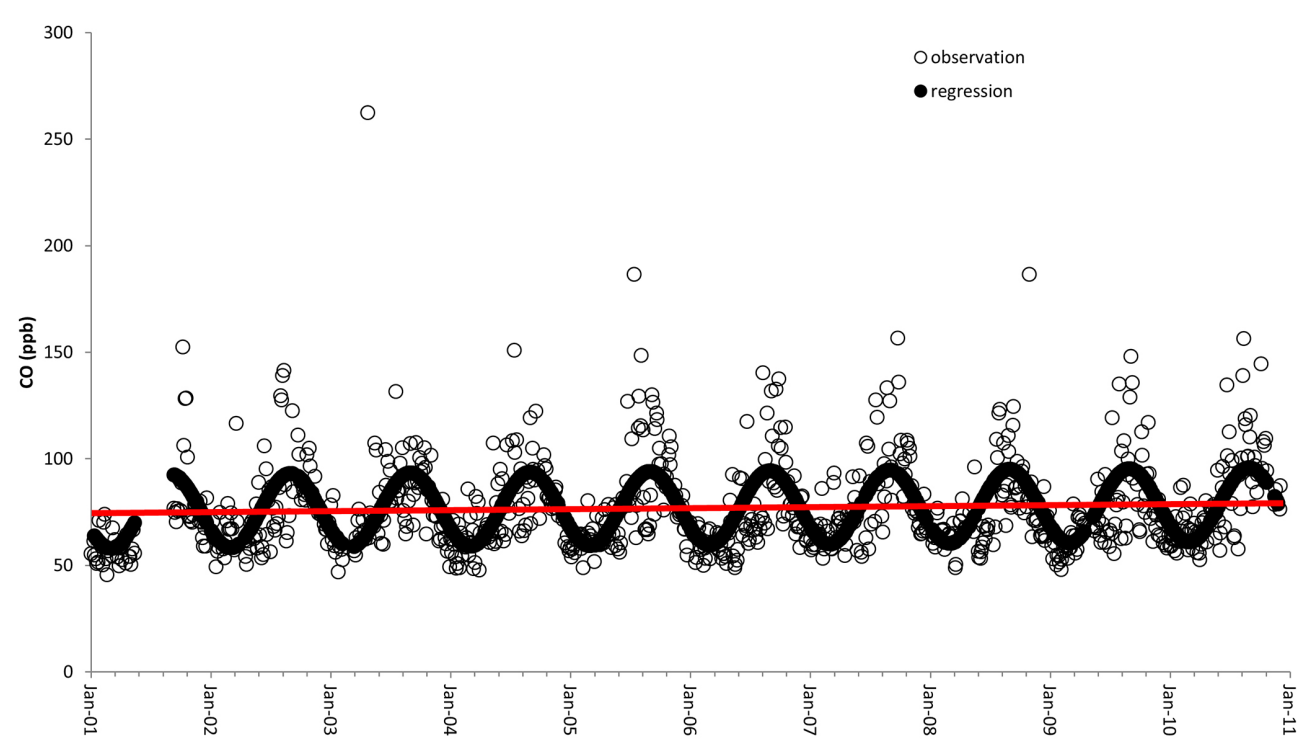

Figure 6. Time evolution of CO concentrations (ppb) in 2001-2010 at Ascension Island. A trend line is shown in red.

\subsection{Impacts of global change on tropospheric composition in the tropics and Southern Hemisphere}

We examine in this study the potential effects of 2000-2050 changes in both climate and emissions on tropospheric composition in the tropics and the SH. We follow the IPCC A1B scenario (Nakicenovic and Stewart, 2000) for the 2000-2050 changes in climate and emissions of ozone precursors (Wu et al., 2008a).

\subsubsection{Perturbations to tropospheric composition in January due to changes in emissions and climate}

Higher $\mathrm{CO}$ emissions from biomass burning over northern Africa are projected for 2050s following the IPCC A1B scenario (Table 1). This results in higher continental outflow of $\mathrm{CO}$ from northern Africa towards South America across the Atlantic Ocean (Fig. 7a). Compared to the present day, the mixing ratios of $\mathrm{CO}$ in the lower troposphere over the northern Africa coast are simulated to increase by up to $150 \mathrm{ppb}$. General increases are also found for $\mathrm{NO}_{\mathrm{x}}$ concentrations in the lower troposphere $(\leq 2.1 \mathrm{~km}$ a.s.l.) driven by increases in both biomass burning and fossil fuel emissions (Table 1). Increases of $\mathrm{O}_{3}$ by $20-35 \%$ are predicted over the Atlantic Ocean just north of the Equator.

We further examine the future changes in January $\mathrm{O}_{3}$ in the middle and upper tropospheric $\mathrm{O}_{3}$ over the $\mathrm{SAO}$, which are related to the well-known tropical Atlantic ozone paradox (Thompson et al., 2000; Edwards et al., 2003). Lightning is a major source of $\mathrm{NO}_{\mathrm{x}}$ in the middle and upper troposphere. Emissions of $\mathrm{NO}_{\mathrm{x}}$ from lightning are projected to increase over southern Africa and South America by $18.2 \%$ and $16.4 \%$ (Table 1), respectively. Future $\mathrm{O}_{3}$ concentrations are predicted to increase by $10-25 \%$ in the upper troposphere over the $\mathrm{SAO}$ at latitudes $5-25^{\circ} \mathrm{S}$ (Fig. 7 b). $\mathrm{O}_{3}$ concentrations in the mid-troposphere are simulated to have no changes or even decreases in the lower latitudes $\left(<15^{\circ} \mathrm{S}\right)$ but increases in the higher latitudes $\left(>20^{\circ} \mathrm{S}\right)$ in the $2050 \mathrm{~s}$ (Fig. 7c). Brasseur et al. (2006) reported similar findings over this area in their study although their results were for July. The future changes in $\mathrm{O}_{3}$ appear to be primarily driven by the changes in cloudiness and therefore solar radiation (Fig. 7d). The decreases in clouds around $25-30^{\circ} \mathrm{S}$ increase solar radiation and hence $\mathrm{O}_{3}$ production there, whereas the increase in clouds between $0-20^{\circ} \mathrm{S}$ and $0-30^{\circ} \mathrm{W}$ leads to a reduction in $\mathrm{O}_{3}$ in that region. The changes in humidity can also contribute to the changes in $\mathrm{O}_{3}$ by affecting the photochemical $\mathrm{O}_{3}$ destruction. We find significant decreases in specific humidity around $25-30^{\circ} \mathrm{S}$ over the SAO (Fig. 7e).

\subsubsection{Perturbations to tropospheric composition in September due to changes in emissions and climate}

Over southern Africa, reductions in September CO concentrations by up to $15 \%$ are simulated over $10-20^{\circ} \mathrm{S}$ (Fig. 8a) in the 2050s. This results from the combination of decreasing biomass burning emissions and large growth in fossil fuel combustion (Table 1) in South Africa, Republic of the Congo, and Gabon. In South America, however, the large growth in $\mathrm{CO}$ emissions from biomass burning results in high $\mathrm{CO}$ concentrations of exceeding $450 \mathrm{ppb}$ (or increase by more than $90 \%$ ) in the lower troposphere (Fig. 8b) over almost the entire southern tropical and subtropical $\left(0-20^{\circ} \mathrm{S}\right)$ continent. Lower tropospheric $\mathrm{CO}$ concentrations near the center of SAO $\left(15^{\circ} \mathrm{S}, 15^{\circ} \mathrm{W}\right)$ are predicted to increase by more than $80 \%$ (Fig. 8a) to reach 120 ppb. Reflected by the 
increases in lightning frequency, elevated CO concentrations $(300 \mathrm{ppb})$ found in the upper troposphere (Fig. 8c) over South America in the future demonstrate the importance of deep convection to export biomass burning emissions from the boundary layer to the middle and upper troposphere. $\mathrm{CO}$ is then input into the SAO by upper-level westerlies, resulting in maximum increases in $\mathrm{CO}$ by $80-90 \%$ there.

The impact on $\mathrm{NO}_{\mathrm{x}}$ from reductions in biomass burning (by $46 \%$ ) in southern Africa is counterbalanced by projected large increases (by 3.8 times in Table 1) in fossil fuel emissions. The consequential effects on the lower tropospheric $\mathrm{NO}_{\mathrm{x}}$ concentrations are shown in Fig. 8d. The present maximum in $\mathrm{NO}_{\mathrm{x}}$ concentrations located over the biomass burning region (between 10 and $20^{\circ} \mathrm{S}$ over southern Africa) is projected to be replaced by two maxima in 2050: one similarly located over the biomass burning, but reduced in magnitude, and another over South Africa, due to large increases in fossil fuel emissions. Similar patterns are found for $\mathrm{O}_{3}$ (Fig. 8e), indicating the critical role of $\mathrm{NO}_{\mathrm{x}}$ in controlling $\mathrm{O}_{3}$ in the tropics. Figure 8e shows two outflow pathways of $\mathrm{O}_{3}$ from southern Africa. One of them from southern Africa into the mentioned SAO area is clearly seen, leading to the conclusion that the lower tropospheric $\mathrm{O}_{3}$ from the continent contributes largely to $\mathrm{O}_{3}$ concentrations over the SAO. Another pathway to the Indian Ocean, which is not pronounced in the present day but in the future, is due to the significant increases in fossil fuel $\mathrm{NO}_{\mathrm{x}}$ emissions in South Africa and the effects of the persistent anticyclone. A sensitivity simulation, where fossil fuel emissions were excluded from South Africa, indicates that fossil fuel emissions would contribute to the total $\mathrm{O}_{3}$ over South Africa by up to $60 \%$ in 2050 s (Fig. 8f).

PAN is produced by photochemical oxidation of NMVOC in the presence of $\mathrm{NO}_{\mathrm{x}}$, and thus its concentrations are higher near $\mathrm{NO}_{\mathrm{x}}$ sources (Fig. 9). In present day, PAN concentrations in the lower troposphere are simulated to be low $(<0.03 \mathrm{ppb})$ over the SAO and the Indian Ocean. In the 2050s, PAN concentrations in the lower troposphere are enhanced by the increases in $\mathrm{NO}_{\mathrm{x}}$ emissions from both continents and reach $0.07 \mathrm{ppb}$ over remote oceans in the higher latitudes $\left(>35^{\circ} \mathrm{S}\right)$ far away from the continents to the regions near Australia, despite higher future temperatures reducing the potential of LRT of PAN (Wu et al., 2008a). The major contribution from fossil fuel emissions is demonstrated by a sensitivity simulation that excludes fossil fuel emissions (Fig. 9c). Enhanced PAN concentrations in the 2050s in the southern midlatitudes are due to southeastern outflows of PAN from southern Africa (produced by high $\mathrm{NO}_{\mathrm{x}}$ emissions in South Africa and nearby areas) to the Indian Ocean, the effects of anticyclone, and the contribution of PAN production from South America. The distinct zonal gradient of PAN concentrations over the Indian Ocean and further east in the higher latitudes is maintained by the westerlies and lower temperatures, which stabilizes PAN. It has implications for the $\mathrm{O}_{3}$ budget over the remote oceans since PAN acts as a low-temperature reservoir of $\mathrm{NO}_{\mathrm{x}}$. PAN serves as a source of $\mathrm{NO}_{\mathrm{x}}$ once it undergoes thermal dissociation at higher temperature and thus contributes to $\mathrm{O}_{3}$ formation. The contribution of fossil fuel emissions from South America to the mid- and upper tropospheric PAN in 2050s is found to be relatively small as compared with that from biomass burning.

Increases in future $\mathrm{O}_{3}$ concentrations are predicted throughout the troposphere over the SAO. The increases are relatively small $(\sim 5 \mathrm{ppb})$ below $3 \mathrm{~km}$ a.s.l. but large ( $\sim 20 \mathrm{ppb}$ ) above $8 \mathrm{~km}$ a.s.l. It is interesting to discuss further the $\mathrm{O}_{3}$ contribution over the $\mathrm{SAO}$, which attracts continuous attention from the scientific community (Singh et al., 1996; Jacob et al., 1996; Jourdain et al., 2007) due to the unique meteorological and emission settings. We carry out a series of sensitivity model simulations to examine the contributions to total ozone over the remote SAO from various sources. Results from a specific sensitivity simulation by excluding certain emission source (e.g., biomass burning, lightning, fossil fuel combustion, soil emissions) are compared with the control run to derive the contribution from that source. Figure 10 shows the vertical profiles of total $\mathrm{O}_{3}$ over the remote $\mathrm{SAO}$ as well as the contributions from biomass burning and lightning sources. The dominant effects on tropospheric $\mathrm{O}_{3}$ from biomass burning and lightning are found in the lower and upper troposphere, respectively. Lightning $\mathrm{NO}_{x}$ enhances $\mathrm{O}_{3}$ in the upper troposphere by up to $24 \mathrm{ppb}$. The contribution of soil $\mathrm{NO}_{\mathrm{x}}$ emissions is found to be negligibly small. We also find that the total emissions from southern Africa and South America can account for up to $45 \%$ of the total ozone over the SAO at any level in the troposphere.

\subsubsection{Impacts on hydroxyl radical}

Our results show that for January in the present day, biomass burnings in northern Africa near the Equator have little impact on $\mathrm{OH}$ concentrations in the lower troposphere, reflecting the compensating effects from increasing $\mathrm{NO}_{\mathrm{x}}$ and $\mathrm{CO}$. In January of 2050s, the increases in burning emissions lead to relatively small changes in $\mathrm{OH}$ concentrations $(<10 \%)$ in the lower troposphere over the burning areas in northern Africa and the adjacent Atlantic Ocean to the west of the continent. In the lower and middle troposphere over the SAO, despite the increases in $\mathrm{O}_{3}$ concentrations predicted in future, $\mathrm{OH}$ concentrations are simulated to decrease by up to $20 \%$, which are attributed to the assumed increases in $\mathrm{CH}_{4}$ in the model (from $\sim 1750 \mathrm{ppb}$ in present day to $2400 \mathrm{ppb}$ in 2050s) (Wu et al., 2008a).

In the simulation for September in the 2050s, the remote oceanic areas including the SAO, the Indian Ocean to the east of southern Africa, and the Pacific Ocean to the west of South America will be featured with hemispheric decreases in $\mathrm{OH}$ concentrations in the boundary layer by up to $30 \%$ compared to the present-day simulation (Fig. 11). The decreases in $\mathrm{OH}$ over the remote oceans reflect the future increases in methane and $\mathrm{CO}$, which are primary sinks for $\mathrm{OH}$. The multi-model 
a) Co difference

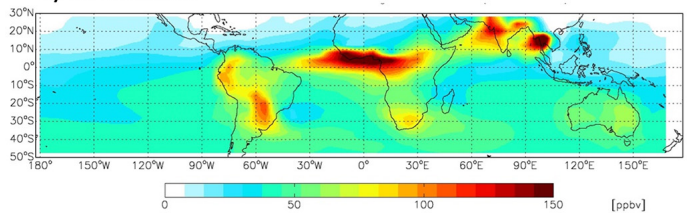

c) $\mathrm{O}_{3}$ difference, mid-troposphere

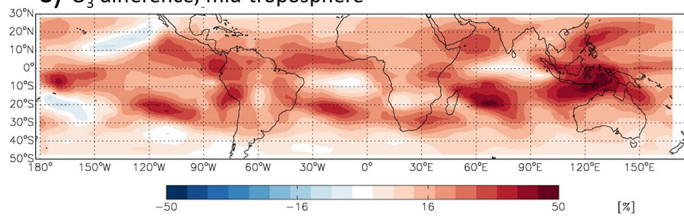

e) Difference of specific humidity

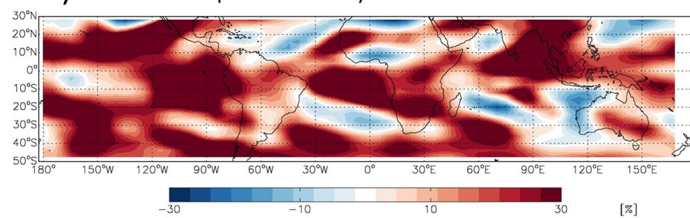

b) $\mathrm{O}_{3}$ difference, upper troposphere

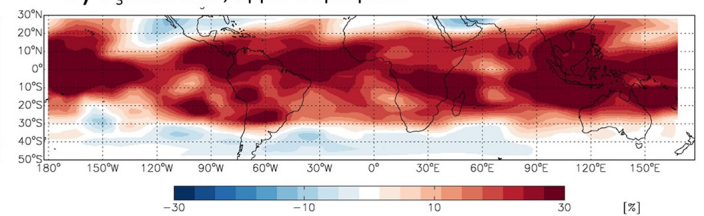

d) Difference of column cloud fraction

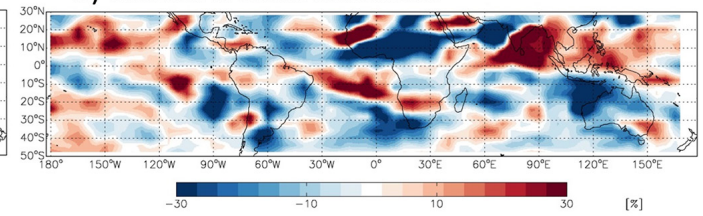

f) OH difference

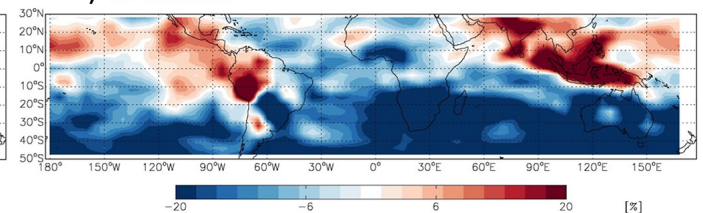

Figure 7. Difference plot (2050s-2000s) of lower tropospheric CO distribution (ppb) over northern Africa coast and Atlantic Ocean in January (a). Percentage difference (2050s-2000s) of $\mathrm{O}_{3}$ distribution in upper troposphere (7.6-12.8 km) (b), and mid-troposphere (2.1$7.6 \mathrm{~km})(\mathbf{c})$, column cloud fraction $(\mathbf{d})$, specific humidity $(\mathbf{e})$, and $\mathrm{OH}(\mathbf{f})$ in mid-troposphere over the SAO in January.

a) co difference

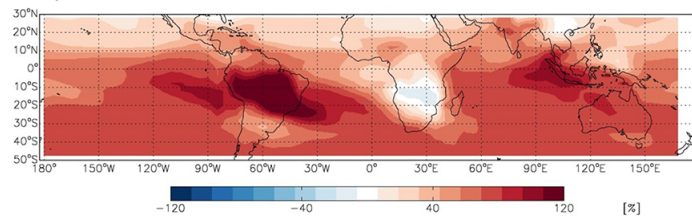

c) co, upper troposphere

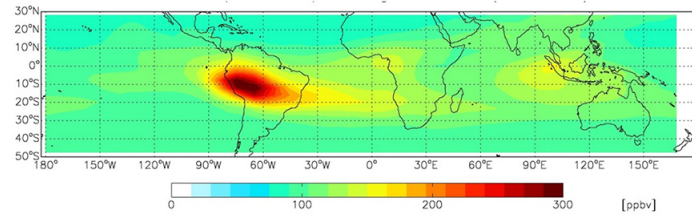

e) $\mathrm{O}_{3}$

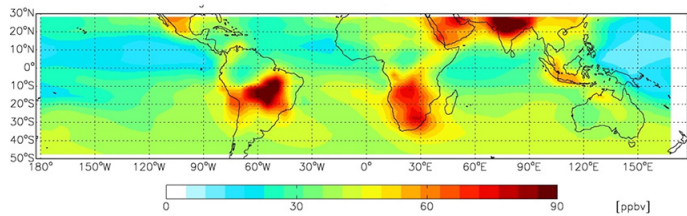

b) co, lower troposphere

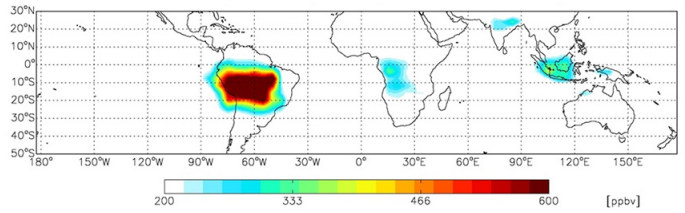

d) $\mathrm{NO}_{x}$

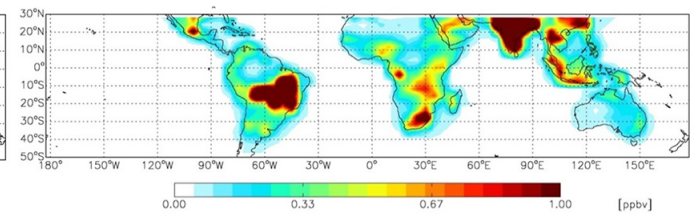

f) $O_{3}$, fossil fuel contribution

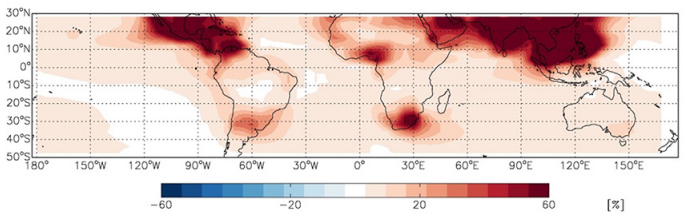

Figure 8. Percentage difference (2050s-2000s) of CO distribution in lower troposphere (a), CO concentrations (ppb) in lower (b) and upper (c) troposphere, lower tropospheric $\mathrm{NO}_{\mathrm{x}}(\mathbf{d})$ and $\mathrm{O}_{3}(\mathbf{e})$ distribution (ppb), and fossil fuel contribution to total $\mathrm{O}_{3}$ (f) in future $\mathrm{September}$. 


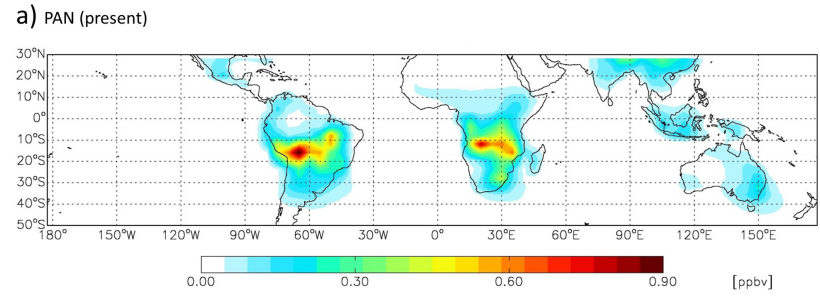

b) PAN (future)

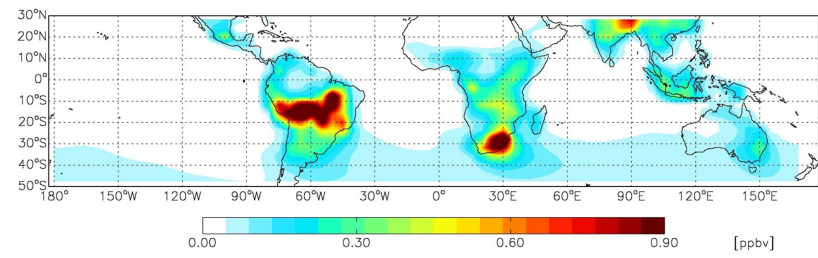

C) PAN (future, no fossil fuel contribution)

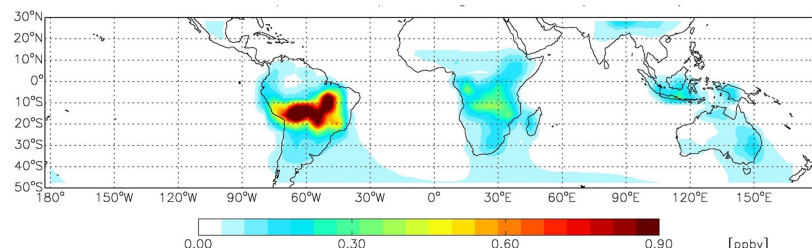

Figure 9. Lower tropospheric PAN distribution (ppb) over southern Africa, South America, the remote SAO and Indian Ocean in present September (a), future September (b) and that excluding the fossil fuel contribution (c).

study by Voulgarakis et al. (2013) also reported large reduction (by 24 to $36 \%$ ) in their simulated $\mathrm{OH}$ over these $\mathrm{SH}$ regions in 2100 following the IPCC RCP 8.5 scenario. In addition, we find even larger $\mathrm{OH}$ reductions (by up to $60 \%$ ) over southern Africa, which appear driven by the additional effects associated with increasing biogenic VOC (in particular isoprene) emissions in the future climate. Biogenic VOC emissions in our model follow the MEGAN scheme (Guenther et al., 2006) and increase with temperature. On the other hand, increases in $\mathrm{OH}$ by up to $50 \%$ are calculated over large areas in South America, reflecting the projected large increases in $\mathrm{NO}_{\mathrm{x}}$ emissions from biomass burning (Table 1).

Negative changes in annual $\mathrm{OH}$ concentrations are simulated in marine boundary layer in the tropics and the $\mathrm{SH}$ in future in our simulation, which agree with the reductions simulated by a 3-D global CTM (Wild and Palmer, 2008) and a 1-D photochemical model (Thompson et al., 1990). Meanwhile, our model predicts similar $\mathrm{OH}$ concentrations in the upper troposphere over the SH for present day and future (figures not shown). The increases in $\mathrm{OH}$ production in the upper troposphere in the future are attributed to NO from lightning, which plays an important role to offset the $\mathrm{OH}$ loss. Wu et al. (2008a) also reported the global increase
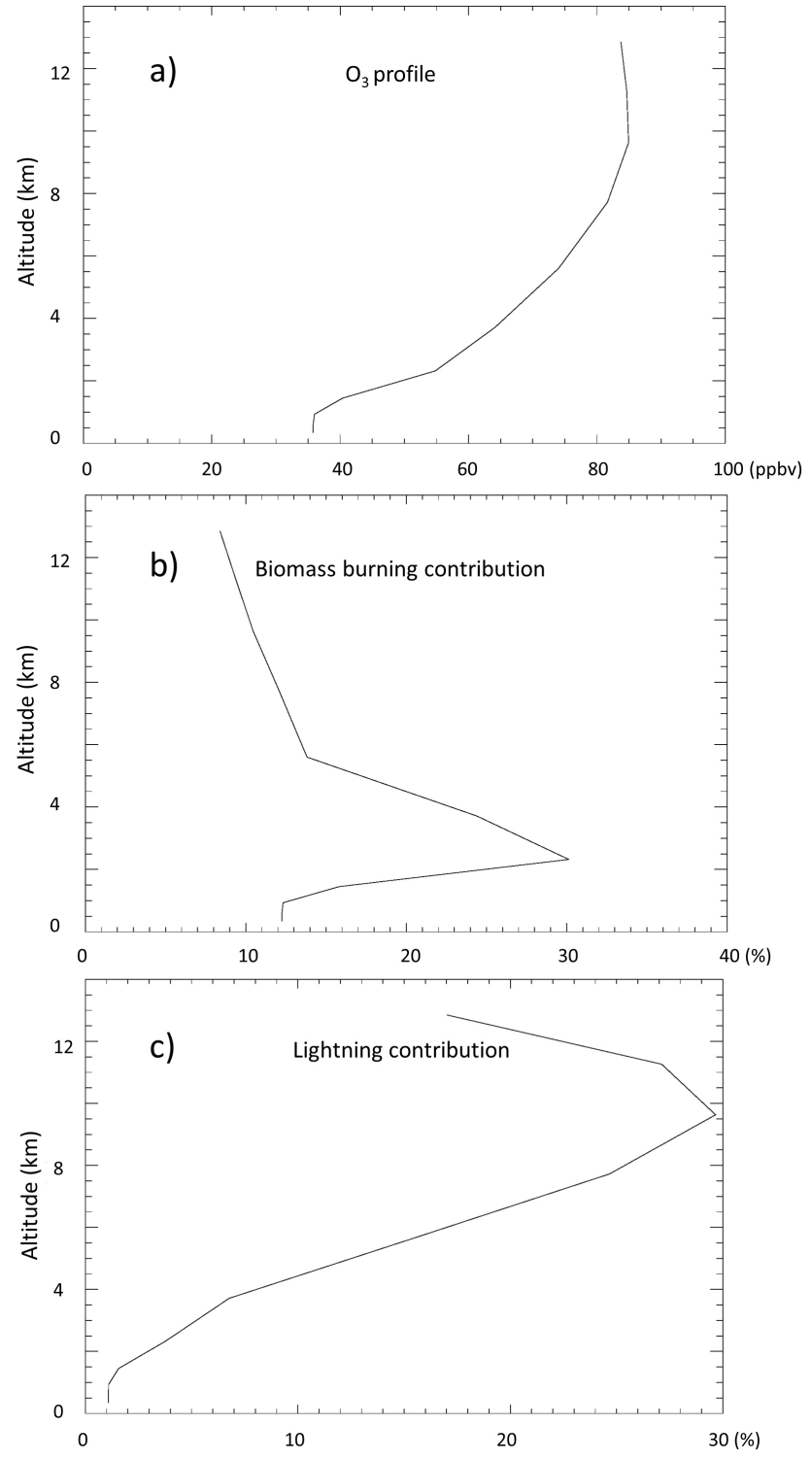

Figure 10. Vertical profiles of total $\mathrm{O}_{3}$ concentrations (ppb) (a) with biomass burning (b) and lightning (c) contribution in percentage over the SAO (defined as an area within $25^{\circ} \mathrm{S}, 25^{\circ} \mathrm{W}$ and $5^{\circ} \mathrm{S}$, $\left.5^{\circ} \mathrm{E}\right)$ in future September.

in $\mathrm{OH}$ by $12 \%$ in the upper troposphere due to increases in lightning frequency in 2050.

\section{Conclusions}

A combination of in situ measurements, global chemical transport modeling, back-trajectory analyses, and satellite observations were used to examine the $\mathrm{CO}$ variability in the tropics and the $\mathrm{SH}$ in the recent years due to the impacts of biomass burning. Our model results show reasonable agreement with observations. Clear seasonal variations in 


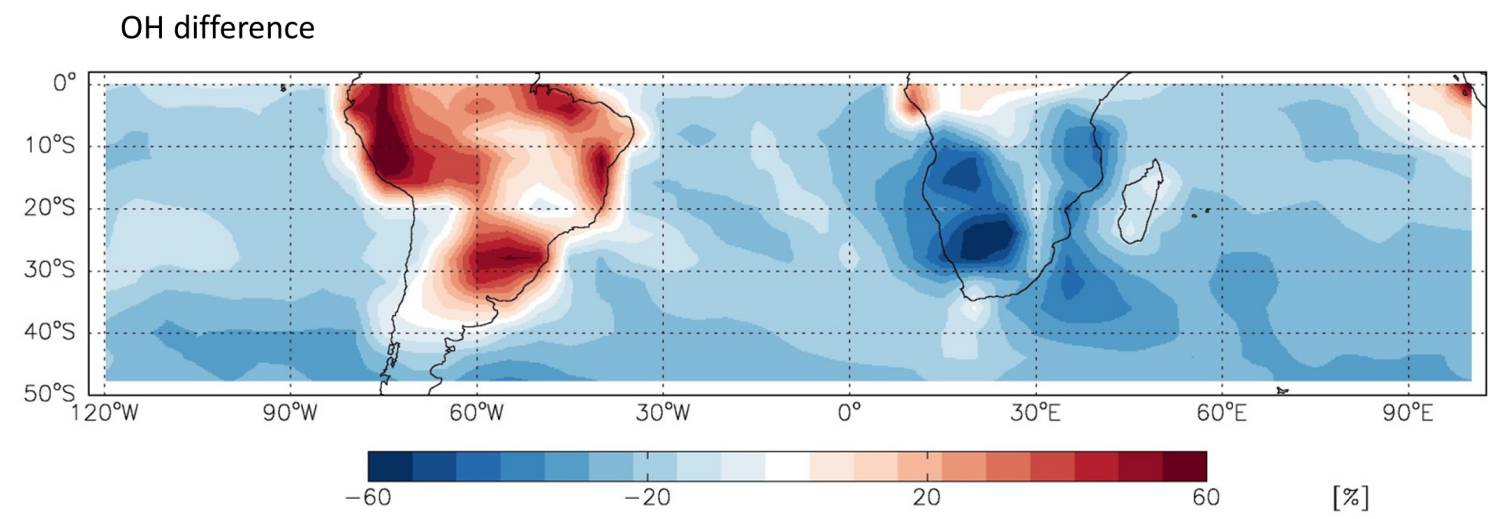

Figure 11. Percentage difference of boundary-layer $\mathrm{OH}$ between present and future over tropical areas and SH in September.

$\mathrm{CO}$ were found at all the three remote islands (Ascension Island, Mahé, and Easter Island) located in the SH near southern Africa and South America, but Ascension Island is the only site impacted directly by the continental-scale burning activities. A statistically significant increasing trend of $\mathrm{CO}$ at Ascension Island is identified for the period of 2001-2010.

Sensitivity simulations are conducted to examine the perturbations to tropospheric composition in the tropics and the SH due to projected changes in emissions and climate between 2000 and 2050. In 2050s, lower tropospheric CO concentrations of up to $500 \mathrm{ppb}$ are simulated over Africa in January, which are mainly caused by increases in biomass burning emissions. With increases in $\mathrm{NO}_{\mathrm{x}}$ emissions from both biomass burning and fossil fuel, increases in $\mathrm{O}_{3}$ by $20-35 \%$ across the Atlantic Ocean just north of the Equator are predicted. In the 2050s, export of the burning emissions from the boundary layer to the middle and upper troposphere over South America by deep convection leads to maximum CO concentrations of $\sim 300 \mathrm{ppb}$ in September. It is found that emissions (including lightning $\mathrm{NO}_{\mathrm{x}}$ sources) from southern Africa and South America contribute up to $45 \%$ to the total tropospheric ozone over the SAO. Biomass burning is found to be most important in the lower troposphere while lightning is most important in the upper troposphere in affecting tropospheric ozone. In 2050s, PAN concentrations in the lower troposphere are enhanced by the increases in $\mathrm{NO}_{\mathrm{x}}$ emissions in both continents, which are simulated to reach $0.07 \mathrm{ppb}$ over the remote oceans in the higher latitudes $\left(>35^{\circ} \mathrm{S}\right)$ far away from the continents to the region near Australia.

Under the 2050s conditions, general decreases in $\mathrm{OH}$ concentrations, by up $30 \%$ compared to the present-day levels, are simulated in the Southern Hemisphere, driven by the increases in $\mathrm{CO}$ and VOC emissions. The most noticeable region of exception is South America, where the $\mathrm{OH}$ is calculated to increase by up to $50 \%$, reflecting the large increases in $\mathrm{NO}_{\mathrm{x}}$ emissions there. Our results show that both biomass burning and climate change are important in affecting the long-term evolution of tropospheric ozone and $\mathrm{OH}$ in the Southern Hemisphere, which in turn can affect regional climate and air quality.

\section{The Supplement related to this article is available online at doi:10.5194/acp-14-4859-2014-supplement.}

Acknowledgements. This publication was made possible by USEPA grant (grant 83518901). Its contents are solely the responsibility of the grantee and do not necessarily represent the official views of the USEPA. Further, USEPA does not endorse the purchase of any commercial products or services mentioned in the publication. The authors acknowledge the NOAA Air Resources Laboratory (ARL) for the provision of the HYSPLIT model used in this publication. We also acknowledge (1) P. C. Novelli and his team for the provision of the $\mathrm{CO}$ surface measurements at Ascension Island as a station in the NOAA/ESRL GMD network and (2) the use of Rapid Response imagery from the LANCE system operated by the NASA/GSFC/ESDIS with funding provided by NASA/HQ.

Edited by: D. Spracklen

\section{References}

Allen, D. J., Kasibhatla, P., Thompson, A. M., Rood, R. B., Doddridge, B. G., Pickering, K. E., Hudson, R. D., and Lin, S.-J.: Transport-induced interannual variability of carbon monoxide determined using a chemistry and transport model, J. Geophys. Res., 101, 28655-28669, 1996.

Anderson, B. E., Grant, W. B., Gregory, G. L., Browell, E. V., Collins Jr., J. E., Sachse, G. W., Bagwell, D. R., Hudgins, C. H., Blake, D. R., and Blake, N. J.: Aerosols from biomass burning over the tropical South Atlantic region: distributions and impacts, J. Geophys. Res., 101, 24117-24137, 1996.

Andreae, M., Fishman, J., and Lindesay, J.: The Southern Tropical Atlantic Region Experiment (STARE): Transport and Atmospheric Chemistry near the Equator Atlantic (TRACE A) and Southern African Fire Atmosphere Research Initiative (SA- 
FARI): an introduction, J. Geophys. Res., 101, 23519-23520, 1996.

Barbosa, P. M., Stroppiana, D., Gregoire, J.-M., and Pereira, J. M. C.: An assessment of vegeta tion fire in Africa (19811991): burned areas, burned biomass, and atmospheric emissions, Global Biogeochem. Cy., 13, 933-950, 1999.

Bevan, S. L., North, P. R. J., Grey, W. M. F., Los, S. O., and Plummer, S. E.: Impact of atmospheric aerosol from biomass burning on Amazon dry-season drought, J. Geophys. Res., 114, D09204, doi:10.1029/2008JD011112, 2009.

Bey, I., Jacob, D. J., Yantosca, R. M., Logan, J. A., Field, B. D., Fiore, A. M., Li, Q., Liu, H. Y., Mickley, L. J., and Schultz, M. G.: Global modeling of tropospheric chemistry with assimilated meteorology: model description and evaluation, J. Geophys. Res., 106, 23073-23095, 2001.

Bian, H., Chin, M., Kawa, S. R., Duncan, B., Arellano, A., and Kasibhatla, P.: Sensitivity of global CO simulations to uncertainties in biomass burning sources, J. Geophys. Res., 112, D23308, doi:10.1029/2006JD008376, 2007.

Brasseur, G. P., Schultz, M., Granier, C., Saunois, M., Diehl, T., Botzet., M., Roeckner, E., and Walters, S.: Impact of climate change on the future chemical composition of the global troposphere, J. Climate, 19, 3932-3951, doi:10.1175/JCLI3832.1, 2006.

Dlugokencky, E. J., Bruhwiler, L., White, J. W. C., Emmons, L. K., Novelli, P. C., Montzka, S. A., Masarie, K. A., Lang, P. M., Crotwell, A. M., Miller, J. B., and Gatti, L. V.: Observational constraints on recent increases in the atmospheric $\mathrm{CH}_{4}$ burden, Geophys. Res. Lett., 36, L18803, doi:10.1029/2009GL039780, 2009.

Draxler, R. R. and Rolph, G. D.: HYSPLIT (HYbrid Single-Particle Lagrangian Integrated Trajec- tory) Model access via NOAA ARL READY Website, NOAA Air Resources Laboratory, Silver Spring, MD, available at: http://ready.arl.noaa.gov/HYSPLIT. php (last access: 28 July 2013), 2013.

Duncan, B. N., Martin, R. V., Staudt, A. C., Yevich, R., and Logan, J. A.: Interannual and sea- sonal variability of biomass burning emissions constrained by satellite observations, J. Geophys. Res., 108, 4100, doi:10.1029/2002JD002378, 2003.

Duncan, B. N., Logan, J. A., Bey, I., Megretskaia, I. A., Yantosca, R. M., Novelli, P. C., Jones, N. B., and Rinsland, C. P.: Global budget of CO, 1988-1997: Source estimates and validation with a global model, J. Geophys. Res., 112, D22301, doi:10.1029/2007JD008459, 2007.

Edwards, D. P., Lamarque, J.-F., Attieé, J.-L., Emmons, L. K., Richter, A., Cammas, J.-P., Gille, J. C., Francis, G. L., Deeter, M. N., Warner, J., Ziskin, D. C., Lyjak, L. V., Drummond, J. R., and Burrows, J. P.: Tropospheric ozone over the tropical Atlantic: a satellite perspective, J. Geophys. Res., 108, 4237, doi:10.1029/2002JD002927, 2003.

Edwards, D. P., Emmons, L. K., Gille, J. C., Chu, A.,. Attieé, J.-L., Giglio, L., Wood, S. W., Haywood, J., Deeter, M. N., Massie, S. T., Ziskin, D. C., and Drummond, J. R.: Satellite observed pollution from Southern Hemisphere biomass burning, J. Geophys. Res., 111, D14312, doi:10.1029/2005JD006655, 2006.

Fiore, A. M., Jacob, D. J., Liu, H., Yantosca, R. M., Fairlie, T. D., and Li, Q.: Variability in surface ozone background over the United States: implications for air quality policy, J. Geophys. Res., 108, 4787, doi:10.1029/2003JD003855, 2003.
Fishman, J., Hoell Jr., J., Bendura, R., McNeal, R., and Kirchhoff, V.: NASA GTE TRACE A experiment (September-October 1992): overview, J. Geophys. Res., 101, 23865-23879, 1996.

Freitas, S. R., Longo, K. M., Silva Dias, M. A. F., Silva Dias, P. L., Chatfield, R., Prins, E., Artaxo, P., Grell, G. A., and Recuero, F. S.: Monitoring the transport of biomass burning emissions in South America, Environ. Fluid Mech., 5, 135-167, 2005.

Galanter, M., Levy II, H., and Carmichael, G. R.: Impacts of biomass burning on tropospheric $\mathrm{CO}, \mathrm{NO}_{\mathrm{x}}$, and $\mathrm{O}_{3}$, J. Geophys. Res., 105, 6633-6653, 2000.

Granier, C., Müller, J., and Brasseur, G.: The impact of biomass burning on the global budget of ozone and ozone Precursors, Adv. Glob. Change Res., 3, 69-85, 2000.

Grenfell, J. L., Shindell, D. T., and Grewe, V.: Sensitivity studies of oxidative changes in the troposphere in 2100 using the GISS GCM, Atmos. Chem. Phys., 3, 1267-1283, doi:10.5194/acp-31267-2003, 2003.

Guenther, A., Karl, T., Harley, P., Wiedinmyer, C., Palmer, P. I., and Geron, C.: Estimates of global terrestrial isoprene emissions using MEGAN (Model of Emissions of Gases and Aerosols from Nature), Atmos. Chem. Phys., 6, 3181-3210, doi:10.5194/acp-63181-2006, 2006.

Haywood, J. M., Pelon, J., Formenti, P., Bharmal, N., Brooks, M., Capes, G., Chazette, P., Chou, C., Christopher, S., Coe, H., Cuesta, J., Derimian, Y., Desboeufs, K., Greed, G., Harrison, M., Heese, B., Highwood, E. J., Johnson, B., Mallet, M., Marticorena, B., Marsham, J., Milton, S., Myhre, G., Osborne, S. R., Parker, D. J., Rajot, J.-L., Schulz, M., Slingo, A., Tanré, D., P. Tulet : Overview of the dust and biomass-burning experiment and African mon- soon multidisciplinary analysis special observing period-0, J. Geophys. Res., 113, D00C17, doi:10.1029/2008JD010077, 2008.

Heald, C. L., Jacob, D. J., Turquety, S., Hudman, R. C., Weber, R. J., Sullivan, A. P., Peltier, R. E., Atlas, E. L., de Gouw, J. A., Warneke, C., Holloway, J. S., Neuman, A. J., Flocke, F. M., and Seinfeld J. H.: Concentrations and sources of organic carbon aerosols in the free troposphere over North America, J. Geophys. Res., 111, D23S47, doi:10.1029/2006JD007705, 2006.

Hedegaard, G. B., Brandt, J., Christensen, J. H., Frohn, L. M., Geels, C., Hansen, K. M., and Stendel, M.: Impacts of climate change on air pollution levels in the Northern Hemisphere with special focus on Europe and the Arctic, Atmos. Chem. Phys., 8, 3337-3367, doi:10.5194/acp-8-3337-2008, 2008.

Hickman, J. S., Wu, S., Mickley, L. J., and Lerdau, M. T.: Kudzu (Pueraria montana) invasion doubles emissions of nitric oxide and increases ozone pollution, P. Natl. Acad. Sci. USA, 107, 10115-10119, doi:10.1073/pnas.0912279107, 2010.

Hsu, N. C., Herman, J. R., Bhartia, P. K., Seftor, C. J., Torres, O., Thompson, A. M., Gleason, J. F., Eck, T. F., and Holben, B. N.: Detection of biomass burning smoke from TOMS measurements, Geophys. Res. Lett., 23, 745-748, 1996.

Huang, Y., Wu, S., Dubey, M. K., and French, N. H. F.: Impact of aging mechanism on model simulated carbonaceous aerosols, Atmos. Chem. Phys., 13, 6329-6343, doi:10.5194/acp-13-63292013, 2013.

Hudman, R. C., Murray, L. T., Jacob, D. J., Turquety, S., Wu, S., Millet, D. B., Avery, M., Goldstein, A. H., Holloway, J., and Ryerson, T.: North American influence on tropospheric ozone and the effects of recent emission reductions: constraints 
from ICARTT observations, J. Geophys. Res., 114, D07302, doi:10.1029/2008JD010126, 2009.

IMAGE Team: The Image 2.2 implementation of the SRES scenarios, Publ. 481508018, CD-ROM, Natl. Inst. for Public Heath and the Environ., Bilthoven, the Netherlands, July, 2001.

Jacob, D. J., Heikes, E. G., Fan, S.-M., Logan, J. A., Mauzerall, D. L., Bradshaw, J. D., Singh, H. B., Gregory, G. L., Talbot, R. W., Blake, D. R., and Sachse, G. W.: Origin of ozone and $\mathrm{NO}_{\mathrm{x}}$ in the tropical troposphere: a photochemical analysis of aircraft observations over the South Atlantic basin, J. Geophys. Res., 101, 24235-24250, 1996.

Jaeglé, L., Jaffe, D. A., Price, H. U., Weiss-Penzias, P., Palmer, P. I., Evans, M. J., Jacob, D. J., and Bey, I.: Sources and budgets for $\mathrm{CO}$ and $\mathrm{O}_{3}$ in the Northeastern Pacific during the spring of 2001: results from the PHOBEA-II experiment, J. Geophys. Res., 108, 8802, doi:10.1029/2002JD003121, 2003.

Jenkins, G. S., Ryu, J.-H., Thompson, A. M., and Witte, J. C.: Linking horizontal and vertical transports of biomass fire emissions to the Tropical Atlantic Ozone Paradox during the Northern Hemisphere winter season: 1999, J. Geophys. Res., 108, 4745, doi:10.1029/2004GL020093, 2003.

Jiang, H., Liao, H., Pye, H. O. T., Wu, S., Mickley, L. J., Seinfeld, J. H., and Zhang, X. Y.: Projected effect of 2000-2050 changes in climate and emissions on aerosol levels in China and associated transboundary transport, Atmos. Chem. Phys., 13, 7937-7960, doi:10.5194/acp-13-7937-2013, 2013.

Johnson, M. S., Meskhidze, N., Solmon, F., Gasso, S., Chuang, P. Y., Gaiero, D. M., Yantosca, R. M., Wu, S., Wang, X., and Carouge, C.: Modeling Dust and Soluble Iron Deposition to the South Atlantic Ocean, J. Geophys. Res., 115, D15202, doi:10.1029/2009JD013311, 2010.

Jourdain, L., Worden, H. M., Worden, J. R., Bowman, K., Li, Q., Eldering, A., Kulawik, S. S., Osterman, G., Boersma, K. F., Fisher, B., Rinsland, C. P., Beer, R., and Gunson, M.: Tropospheric vertical distribution of tropical Atlantic ozone observed by TES during the Northern African biomass burning season, Geophys. Res. Lett., 34, L04810, doi:10.1029/2006GL028284, 2007.

Korontzi, S., Roy, D. P., Justice, C. O., and Ward, D. E.: Modeling and sensitivity analysis of fire emissions in Southern Africa during SAFARI 2000, Remote Sens. Environ., 92, 376-396, 2004.

Kumar, A., Wu, S., Weise, M. F., Honrath, R., Owen, R. C., Helmig, D., Kramer, L., Val Martin, M., and Li, Q.: Free troposphere ozone and carbon monoxide over the North Atlantic for 2001-2011, Atmos. Chem. Phys. Discuss., 13, 153770-15407, doi:10.5194/acpd-13-15377-2013, 2013.

Lam, Y. F., Fu, J. S., Wu, S., and Mickley, L. J.: Impacts of future climate change and effects of biogenic emissions on surface ozone and particulate matter concentrations in the United States, Atmos. Chem. Phys., 11, 4789-4806, doi:10.5194/acp-11-47892011, 2011.

Levine, J. S., Cofer, W. R., Cahoon, D. R., and Winstead, E. L.: Biomass burning: a driver for global change, Environ. Sci. Technol., 29, 120A-125A, 1995.

Li, Q., Jacob, D. J., Munger, J. W., Yantosca, R. M., and Parrish, D. D.: Export of $\mathrm{NO}_{\mathrm{y}}$ from the North American boundary layer: reconciling aircraft observations and global model budgets, J. Geophys. Res., 109, D02109, doi:10.1029/2003JD003912, 2004.
Liao, H., Chen, W.-T., and Seinfeld, J. H.: Role of climate change in global predictions of future tropospheric ozone and aerosols, J. Geophys. Res., 111, D12304, doi:10.1029/2005JD006852, 2006.

McLinden, C. A., Olsen, S. C., Hannegan, B., Wild, O., and Prather, M. J.: Stratospheric ozone in 3-D models: a simple chemistry and the cross-tropopause flux, J. Geophys. Res., 105, 14653-14665, 2000.

Moxim, W. J. and Levy II, H.: A model analysis of the tropical South Atlantic Ocean tropospheric ozone maximum: the interaction of transport and chemistry, J. Geophys. Res., 105, 1739317415, 2000.

Murray, L. T., Logan, J. A., and Jacob, D. J.: Interannual variability in tropical tropospheric ozone and $\mathrm{OH}$ : The role of lightning, J. Geophys. Res. Atmos., 118, doi:10.1002/jgrd.50857, 2013.

Nakicenovic, N. and Swart, R. (Eds.): Special Report on Emissions Scenarios, Cambridge Univ. Press, New York, 2000.

Novelli, P. C. and Masarie, K. A.: Atmospheric Carbon Monoxide Dry Air Mole Fractions from the NOAA ESRL Carbon Cycle Cooperative Global Air Sampling Network, 1988-2011, Version: 2012-09-18, ftp://aftp.cmdl.noaa.gov/data/trace_gases/co/ flask/surface/ (last access: 28 July 2013), 2012.

Novelli, P. C., Masarie, K. A., Lang, P. M., Hall, B. D., Myers, R. C., and Elkins, J. W.: Reanalysis of tropospheric CO trends: effects of the 1997-1998 wildfires, J. Geophys. Res., 108, 4464, doi:10.1029/2002JD003031, 2003.

Pickering, K. E., Wang, Y., Tao, W., Price, C., and Muller, J.: Vertical distributions of lightning $\mathrm{NO}_{\mathrm{x}}$ for use in regional and global chemical transport models, J. Geophys. Res., 103, 31203-31216, 1998.

Price, C. and Rind, D.: A simple lightning parameterization for calculating global lightning distributions, J. Geophys. Res., 97, 9919-9933, 1992.

Pye, H. O. T., Liao, H., Wu, S., Mickley, L. J., Jacob, D. J., Henze, D. K., and Seinfeld, J. H.: Effect of changes in climate and emissions on future sulfate-nitrate-ammonium aerosol levels in the United States, J. Geophys. Res., 114, D01205, doi:10.1029/2008JD010701, 2009.

Rigby, M., Prinn, R. G., Fraser, P. J., Simmonds, P. G., Langenfelds, R. L., Huang, J., Cunnold, D. M., Steele, L. P., Krummel, P. B., Weiss, R. F., O'Doherty, S., Salameh, P. K., Wang, H. J., Harth, C. M., Mühle, J., and Porter, L. W.: Renewed growth of atmospheric methane, Geophys. Res. Lett., 35, L22805, doi:10.1029/2008GL036037, 2008.

Rinsland, C. P., Meier, A., Griffith, D. W. T., and Chiou, L. S.: Ground-based measurements of tropospheric $\mathrm{CO}, \mathrm{C}_{2} \mathrm{H}_{6}$, and $\mathrm{HCN}$ from Australia at $34^{\circ} \mathrm{S}$ latitude during 1997-1998, J. Geophys. Res., 106, 20913-20924, 2001.

Rolph, G. D.: Real-time Environmental Applications and Display sYstem (READY) Website, NOAA Air Resources Laboratory, Silver Spring, MD, available at: http://ready.arl.noaa.gov (last access: 28 July 2013), 2013.

Schneising, O., Buchwitz, M., Reuter, M., Heymann, J., Bovensmann, H., and Burrows, J. P.: Long-term analysis of carbon dioxide and methane column-averaged mole fractions retrieved from SCIAMACHY, Atmos. Chem. Phys., 11, 28632880, doi:10.5194/acp-11-2863-2011, 2011.

Seiler, W., Giehl, H., Brunke, E. G., and Halliday, E.: The seasonality of CO abundance in the Southern Hemisphere, Tellus B, 36, 219-231, doi:10.1111/j.1600-0889.1984.tb00244.x, 1984. 
Shindell, D. T., Faluvegi, G., Unger, N., Aguilar, E., Schmidt, G. A., Koch, D. M., Bauer, S. E., and Miller, R. L.: Simulations of preindustrial, present-day, and 2100 conditions in the NASA GISS composition and climate model G-PUCCINI, Atmos. Chem. Phys., 6, 4427-4459, doi:10.5194/acp-6-4427-2006, 2006.

Singh, H. B., Herlth, R., Kolyer, R., Chatfield, W., Viezee, L. J., Salas, Y., Chen, J. D., Bradshaw, S. T., Sandholm, R., Talbot, G. L., Gregory, B., Anderson, G. W., Sachse, E., Browell, A. S., Bachmeier, D. R., Blake, B., Heikes, D., Jacob, H. E., and Fuelberg: Impact of biomass burning emissions on the composition of the South Atlantic troposphere: reactive nitrogen and ozone, J. Geophys. Res., 101, 24203-24219, 1996.

Sinha, P., Jaeglé, L., Hobbs, P. V., and Liang, Q.: Transport of biomass burning emissions from Southern Africa, J. Geophys. Res., 109, D20204, doi:10.1029/2004JD005044, 2004.

Spracklen, D. V., Mickley, L. J., Logan, J. A., Hudman, R. C., Yevich, R., Flannigan, M. D., and Westerling, A. L.: Impacts of climate change from 2000 to 2050 on wildfire activity and carbonaceous aerosol concentrations in the Western United States, J. Geophys. Res., 114, D20301, doi:10.1029/2008JD010966, 2009.

Streets, D. G., Bond, T. C., Lee, T., and Jang, C.: On the future of carbonaceous aerosol emissions, J. Geophys. Res., 109, D24212, doi:10.1029/2004JD004902, 2004.

Streets, D. G, Zhang, Q., Wang, L., He, K., Hao, J., Wu, Y., Tang, Y., and Carmichael, G. C.: Revisiting China's CO emissions after the Transport and Chemical Evolution over the Pacific (TRACE-P) mission: Synthesis of inventories, atmospheric modeling, and observations, J. Geophys. Res., 111, D14306, doi:10.1029/2006JD007118, 2006.

Sudo, K., Takahashi, M., Kurokawa, J., and Akimoto, H.: CHASER: a global chemical model of the troposphere, 1. Model description, J. Geophys. Res., 107, 4339, doi:10.1029/2001JD001113, 2002.

Swap, R. M., Garstang, M., Macko, S. A., Tyson, P. D., Maenhaut, W., Artaxo, P., Kållberg, P., and Talbot, R.: The long-range transport of Southern African aerosols to the tropical South Atlantic, J. Geophys. Res., 101, 23777-23791, 1996.

Thompson, A. M., Huntley, M. A., and Stewart, R. W.: Perturbations to tropospheric oxidants, 1985-2035 1. Calculations of ozone and $\mathrm{OH}$ in chemically coherent regions, J. Geophys. Res., 95, 9829-9844, 1990.

Thompson, A. M., Doddridge, B. G., Witte, J. C., Hudson, R. D., Luke, W. T., Johnson, J. E., Johnson, B. J., Oltmans, S. J., and Weller, R.: A tropical Atlantic paradox: shipboard and satellite views of a tropospheric ozone maximum and wave-one in January-February 1999, Geophys. Res. Lett., 27, 3317-3320, 2000.

Thompson, A. M., Doddridge, B. G., Witte, J. C., Hudson, R. D., Luke, W. T., Johnson, J. E., Johnson, B. J., Oltmans, S. J., and Weller, R.: Tropical tropospheric ozone and biomass burning, Science, 291, 2128-2132, 2001.

Unger, N., Shindell, D. T., Koch, D. M., Amann, M., Cofala, J., and Streets, D. G.: Influences of man-made emissions and climate changes on tropospheric ozone, methane, and sulfate at 2030 from a broad range of possible futures, J. Geophys. Res., 111, D12313, doi:10.1029/2005JD006518, 2006.

van der Werf, G. R., Randerson, J. T., Giglio, L., Collatz, G. J., Kasibhatla, P. S., and Arellano Jr., A. F.: Interannual variabil- ity in global biomass burning emissions from 1997 to 2004, Atmos. Chem. Phys., 6, 3423-3441, doi:10.5194/acp-6-3423-2006, 2006.

Voulgarakis, A., Naik, V., Lamarque, J.-F., Shindell, D. T., Young, P. J., Prather, M. J., Wild, O., Field, R. D., Bergmann, D., CameronSmith, P., Cionni, I., Collins, W. J., Dalsøren, S. B., Doherty, R. M., Eyring, V., Faluvegi, G., Folberth, G. A., Horowitz, L. W., Josse, B., MacKenzie, I. A., Nagashima, T., Plummer, D. A., Righi, M., Rumbold, S. T., Stevenson, D. S., Strode, S. A., Sudo, K., Szopa, S., and Zeng, G.: Analysis of present day and future $\mathrm{OH}$ and methane lifetime in the ACCMIP simulations, Atmos. Chem. Phys., 13, 2563-2587, doi:10.5194/acp-13-25632013, 2013.

Wang, Y. and Jacob, D. G.: Anthropogenic forcing on tropospheric ozone and $\mathrm{OH}$ since prein- dustrial times, J. Geophys. Res., 103, 31123-31135, 1998.

Wang, Y., Shen, L., Wu, S., Mickley, L., He, J., and Hao, J.: Sensitivity of surface ozone over China to 2000-2050 global changes of climate and emissions, Atmos. Environ, 75, 374-382, 2013.

Westerling, A., Hidalgo, H., Cayan, D., and Swetnam, T.: Warming and earlier spring increases Western US forest wildfire activity, Science, 313, 940-943, 2006.

Wild, O. and Palmer, P. I.: How sensitive is tropospheric oxidation to anthropogenic emissions?, Geophys. Res. Lett., 35, L22802, doi:10.1029/2008GL035718, 2008.

Worden, H. M., Deeter, M. N., Frankenberg, C., George, M., Nichitiu, F., Worden, J., Aben, I., Bowman, K. W., Clerbaux, C., Coheur, P. F., de Laat, A. T. J., Detweiler, R., Drummond, J. R., Edwards, D. P., Gille, J. C., Hurtmans, D., Luo, M., MartínezAlonso, S., Massie, S., Pfister, G., and Warner, J. X.: Decadal record of satellite carbon monoxide observations, Atmos. Chem. Phys., 13, 837-850, doi:10.5194/acp-13-837-2013, 2013.

Wu, L., Su, H., and Jiang, J. H.: Regional simulations of deep convection and biomass burning over South America: 1. Model evaluations using multiple satellite data sets, J. Geophys. Res., 116, D17208, doi:10.1029/2011JD016105, 2011.

Wu, S., Mickley, L. J., Jacob, D. J., Logan, J. A., Yantosca, R. M., and Rind, D.: Why are there large differences between models in global budgets of tropospheric ozone?, J. Geophys. Res., 112, D05302, doi:10.1029/2006JD007801, 2007.

Wu, S., Mickley, L. J., Jacob, D. J., Rind, D., and Streets, D.: Effects of 2000-2050 changes in climate and emissions on global tropospheric ozone and the policy-relevant background ozone in the United States, J. Geophys. Res., 113, D18312, doi:10.1029/2007JD009639, 2008a.

Wu, S., Mickley, L. J., Leibensperger, E. M., Jacob, D. J., Rind, D., and Streets, D. G.: Effects of 2000-2050 global change on ozone air quality in the United States, J. Geophys. Res., 113, D06302, doi:10.1029/2007JD008917, 2008b.

Yevich, R. and Logan, J. A.: An assessment of biofuel use and burning of agricultural waste in the developing world, Global Biogeochem. Cy., 17, 1095, doi:10.1029/2002GB001952, 2003.

Yu, H., Chin, M., Remer, L. A., Kleidman, R. G., Bellouin, N., Bian, H., and Diehl, T.: Variability of marine aerosol finemode fraction and estimates of anthropogenic aerosol component over cloud-free oceans from the Moderate Resolution Imaging Spectro-radiometer (MODIS), J. Geophys. Res., 114, D10206, doi:10.1029/2008JD010648, 2009. 
Zhang, Q., Streets, D. G., Carmichael, G. R., He, K. B., Huo, H., Kannari, A., Klimont, Z., Park, I. S., Reddy, S., Fu, J. S., Chen, D., Duan, L., Lei, Y., Wang, L. T., and Yao, Z. L.: Asian emissions in 2006 for the NASA INTEX-B mission, Atmos. Chem. Phys., 9, 5131-5153, doi:10.5194/acp-9-5131-2009, 2009.
Zhao, T. X.-P., Laszlo, I., Guo, W., Heidinger, A., Cao, C., Jelenak, A., Tarpley, D., and Sullivan, J.: Study of long-term trend in aerosol optical thickness observed from operational AVHRR satellite instrument, J. Geophys. Res., 113, D07201, doi:10.1029/2007JD009061, 2008. 